\title{
Giant water scavenger beetles Hydrophilus subgenus Dibolocelus (Coleoptera: Hydrophilidae) from Mexico with description of two new species
}

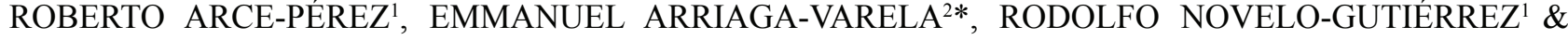 \\ JOSÉ L. NAVARRETE-HEREDIA ${ }^{2}$ \\ ${ }^{1}$ Instituto de Ecología, A.C., Red de Biodiversidad y Sistemática, Carretera Antigua a Coatepec, 351, El Haya, 91070 , Xalapa, Veracruz, \\ Mexico.



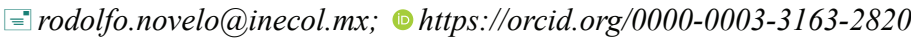 \\ ${ }^{2}$ Centro de Estudios en Zoología, CUCBA, Universidad de Guadalajara, Apdo. postal 134, Zapopan, Jalisco, Mexico. \\ ”"glenusmx@gmail.com; ○ https://orcid.org/0000-0002-3336-8528

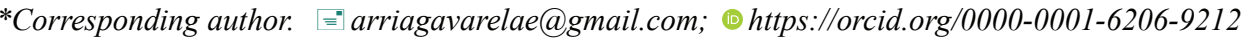

\begin{abstract}
The Hydrophilus (Dibolocelus) Bedel species from Mexico and adjacent areas are treated on the basis of the study of 142 adult specimens and published data. Two new species are herein recognized and described: H. (D.) nucleoensis Arce-Pérez \& Arriaga-Varela sp. nov. from Mexico, Guatemala and Nicaragua, H. (D.) pseudovatus Arce-Pérez \& Arriaga-Varela sp. nov. from Mexico. Three already known species are re-described and their geographical distribution is updated, $H$. (D.) ovatus Gemminger \& Harold and $H$. (D.) pollens Sharp and $H$. (D.) violaceonitens Jacquelin du Val, a species resurrected as distinct to $H$. (D.) smaragdinus. Hydrophylus (D.) cf. purpurascens (Régimbart) is also redescribed but their identity is questionable. The lectotype of $H$. (D.) pollens Sharp is designated. Within Mexico, the state with the highest known diversity is Veracruz with five species. A key to the species of Hydrophilus (Dibolocelus) from Mexico and Central America is provided.
\end{abstract}

Key words: Aquatic beetles, Neotropical region, new taxa, status restored, morphology, distribution

\section{Introduction}

The genus Hydrophilus Geoffroy, 1762 is a group of distinctly large aquatic beetles, with saprophagous or facultative phytophagous habits (Martin Fikáček, personal communication). It is currently composed of 50 species worldwide, classified in three subgenera: Hydrophilus (sensu stricto) Geoffroy, 1762, Dibolocelus Bedel, 1891 and Temnopterus Solier, 1834 (Hansen 1999; Toussaint et al. 2017). The first two are represented in the New World by 19 species: one is found exclusively in the Nearctic, 16 in the Neotropics, and two have their distribution range throughout both zoogeographic regions (Hansen 1999, Short \& McIntosh 2014, 2015). Hansen's (1991) placement of Dibolocelus as a subgenus within Hydrophilus rather than a distinct genus was recently tested and supported by Short (2010) through a morphological phylogenetic analysis of the tribe Hydrophilini that included the study of Hydrophilus species from North and Central America. A molecular phylogeny of tribe Hydrophilini (Toussaint et al. 2017) supported the monophyly of Dibolocelus; however, it seemed to suggest that its inclusion would render Hydrophilus sensu stricto a paraphyletic group. Additional taxonomical sampling is needed in order to have a clear insight of the subgeneric relationships within Hydrophilus. Arce-Pérez \& Morón (2013) reviewed the Hydrophilus s.str. species from Mexico and Central America, updating the known distribution of the species, while Short \& McIntosh (2014) reviewed the Hydrophilus species of the United States of America and Canada, updating their distribution and providing new records from Mexico.

Currently, a total of 10 species of Hydrophilus (Dibolocelus) are known (Hansen 1999; Short \& McIntosh 2014, 2015), one of them is distributed in the Nearctic Region and the remaining nine restricted to the Neotropics. Dibolocelus specimens are not abundant in most of the entomological collections of Mexico and Central America. This situation has led to a scarcity of information about their distribution in the region and uncertainty about the 
presence of certain species. So far, four species are recorded from the area: $H$. (D.) smaragdinus Brulle, $1837, H$. (D.) pollens Sharp, 1887, H. (D.) purpurascens (Régimbart, 1901) and H. (D.) ovatus Gemminger \& Harold, 1868 (Hansen 1999; Arce-Pérez \& Morón 2013; Short \& McIntosh 2014). In this contribution, we update the information about the diversity of this subgenus in Mexico based on the study of specimens deposited in several entomological collections of the country and other Central American countries. The type of $H$. (D.) pollens deposited in the Museum of Natural History, London, UK, was also examined. We describe two new species and re-describe the known species from the region. An illustrated key for the identification of the known species of the subgenus in Mexico and Central America, and updated distribution maps are provided.

\section{Material and methods}

The present contribution is based on the study of 138 specimens of Hydrophilus (Dibolocelus) deposited in the following entomological collections:

$\begin{array}{ll}\text { AOBC } & \text { A. O. Bachmann personal Collection, Argentina (Axel O. Bachmann); } \\ \text { BMNH } & \text { The Natural History Museum, London, United Kingdom (Christine Taylor, Maxwell Barclay); } \\ \text { CNIN } & \begin{array}{l}\text { Colección Nacional de Insectos, Universidad Nacional Autónoma de México, Mexico City, } \\ \text { Mexico (Santiago Zaragoza-Caballero); }\end{array} \\ \text { CZUG } & \begin{array}{l}\text { Centro de Estudios en Zoología, Universidad de Guadalajara, Zapopan, Mexico } \\ \text { (José L. Navarrete-Heredia); }\end{array} \\ \text { INBIO } & \begin{array}{l}\text { Instituto Nacional para la Biodiversidad, Costa Rica (Ángel Solís); } \\ \text { Colección Entomológica, Instituto de Ecología, A.C. Xalapa, Mexico (Roberto Arce-Pérez); }\end{array} \\ \text { INIFAP } & \begin{array}{l}\text { Colección Instituto Nacional de Investigaciones Forestales, Agrícolas y } \\ \text { Pecuarias, Celaya, Mexico (Antonio Marín Jarillo); }\end{array} \\ \text { MNHN } & \text { Muséum National d'Histoire Naturelle, Paris, France (Antoine Mantilleri); } \\ \text { NMPC } & \text { National Museum, Prague, Czech Republic (Martin Fikáček); } \\ \text { SEMC } & \text { University of Kansas, Lawrence, Kansas, USA (Andrew E.Z. Short); } \\ \text { UVGC } & \text { Colección Entomológica, Universidad del Valle de Guatemala, Guatemala, Guatemala } \\ & \text { (Enio Cano). }\end{array}$

The specimens were studied with a Carl Zeiss IV-B or an Olympus SZX 16 stereomicroscope. The microphotographs were taken with a Nikon DS-U3 camera attached to a Nikon SMZ25 stereomicroscope and a Canon EOS 1100D digital camera attached to an Olympus BX41 compound microscope. Habitus photographs were taken using a Canon EOS 550D digital camera with a Canon MP-E65mm f/2.8 1-5× macro lens attached or a Nikon Coolpix P500. The photographs were later processed in Adobe Photoshop CS5 program. Descriptions are based on male specimens and comments on the sexual dimorphism and interspecific variation are provided. Measurements are in millimetres. Geographical coordinates were obtained in Google Earth (https://www.google.com/earth) and provided in brackets, when they were not part of the original label data in the list of studied material. The maps were generated on SimpleMappr (https://www.simplemappr.net/\#tabs=0) and edited with Corel Draw.

\section{Results}

Taxonomy

Hydrophilus (Dibolocelus) Bedel, 1891

Dibolocelus Bedel, 1891: 309.

Type species: Hydrophilus palpalis Brullé, 1837.

Diagnosis. In addition to the characters for the genus (Short 2010), adult Hydrophilus (Dibolocelus) can be differen- 
tiated from those of Hydrophilus (s. str.) by a more convex and robust body shape; maxillary palps usually modified being generally longer, broadened and curved towards apex, sometimes inflated and curved at mid-length, with third palpomere with deep and wide ventral excavation or flat and slightly widened towards the apex; labial palp widely triangular and inflated, clavate or subparallel in shape, with or without setae on lateral margins; fifth protarsomere wide and longer than any of the previous ones, sometimes slightly flattened and with a ventral laminar expansion, never as large as those in Hydrophilus (s.str.); internal spur of anterior tibia flat, sub-rectangular or rounded, with straight or curved external margins, if sub-rectangular then it can be short or long with its apex straight, irregular or clearly bifid; abdominal ventrites 3 and 4 have slight to well-marked oval, glabrous area at mid-line, and ventrite 5 has a wide oblong or sub-triangular glabrous area; ventrites 3 to 5 slightly raised at midline, flattened or forming a keel, slightly projected above ventrite posterior margin.

\title{
Hydrophilus (Dibolocelus) ovatus Gemminger \& Harold, 1868
}

\author{
Figs. 1, 2; 7-10, 41.
}

Hydrophilus ovalis Ziegler, 1844: 45 (primary homonym of Hydrophilus ovalis Brullé, 1837: 53, and Hydrophilus ovalis

Castelnau, 1840: 50).

Dibolocelus ovalis (Ziegler); Régimbart, 1901: 225.

Hydrophilus ovatus Gemminger \& Harold, 1868: 476 (replacement name for Hydrophilus ovalis Ziegler).

Stethoxus ovatus (Gemminger \& Harold); Bedel, 1891: 314.

Hydrous (Dibolocelus) ovatus (Gemminger \& Harold); Kuwert, 1893: 83.

Dibolocelus ovatus (Gemminger \& Harold); Young, 1954: 196.

Studied material. United States of America: Louisiana, New Orleans, 26.vii.1959, At light, W. Gibson col. (3 $\widehat{\jmath}$, 2 ㅇ) [INIFAP].

Diagnosis. This species is distinguished by the following combination of characters: maxillary palpi slender, third palpomere slightly flattened and broadened apically; internal protibial spur sub-rectangular with apex truncated, straight; fifth protarsomere robust, longer than basal ones together. Regarding the characters of body shape, color, vestiture, antenna, maxillary palps and male genitalia, the specimens of $H$. (D.) ovatus from North America, are very similar to those of $H$. (D.) pseudovatus sp. nov. from Mexico but can be distinguished by [characters of $H$. (D.) pseudovatus are provided in brackets for comparative purposes characters of $H$. (D.) pseudovatus] third maxillary palpomere slightly flattened and broadened apically, with its internal margin slightly straight, maximum width $0.080 \mathrm{~mm}$ (Fig. 7) [third maxillary palpomere markedly flattened and broadened toward the apex, with its internal margin slightly convex(Fig. 11)]; fifth protarsomere longer and robust than the basal ones together (Fig. 8) [fifth protarsomere shorter than basal tarsomeres together, flat and with a slight but evident internal laminar expansion (Fig. 12)]; the metaventral spine reaches or exceeds the posterior margin of the second abdominal ventrite (Figs. 2, 9) [short metaventrite spine, not exceeding 3/4 of the second abdominal ventrite (Figs. 4, 13)]; ventrites 3 and 4 raised, with their apical margin slightly acute and slightly projecting over the next ventrite (Fig. 9) [ventrites 3 and 4 slightly raised, with their apical margin slightly rounded and slightly projecting over the following ventrite (Fig. 13)]; ventrites with evident yellowish-reddish lateral oval spot [ventrites without spots].

Description. Body elongate-fusiform, length 30-33 mm, width 17-18 mm at humeri, 1.7-1.8 $\times$ longer than wide, dorsally strongly convex and glabrous, ventrally flat and pubescent; body color black with dark greenish tone, ventrally black with red-yellowish hue, vestiture pale yellow; antennae, palpi and legs dark-reddish, the antennal club slightly lighter.

Head: Antenna short, scape large and robust, longer than the next four antennomeres together; pedicel subequal to the next three antennomeres; sixth long and oval with apex rounded, subequal to previous four together, not covering the first antennomere on the club (Fig. 7). Maxillary palpi long and slender, with four palpomeres, with lengths: $0.4,2.8,2.66,1.4 \mathrm{~mm}$; first palpomere small, subconical; second long, curved and slightly broadened towards apex; third shorter, curved, slightly flattened and broadened towards apex, around $0.80 \mathrm{~mm}$ in its widest part, fourth short and oval, with apex truncated. Mentum broad, hexagonal, 1.8 $\times$ wider at base than long, lateral margins parallel at basal half, apically converging straightly, apex truncated and straight; labial palpi short, length of palpomeres: $0.03,0.08,0.06 \mathrm{~mm}$; first palpomere small and broad; second long and slightly broadened towards apex, $1.3 \times$ longer than the third and with short golden setae at inner margin near apex; third short and oval, with apex rounded (Fig. 7). 

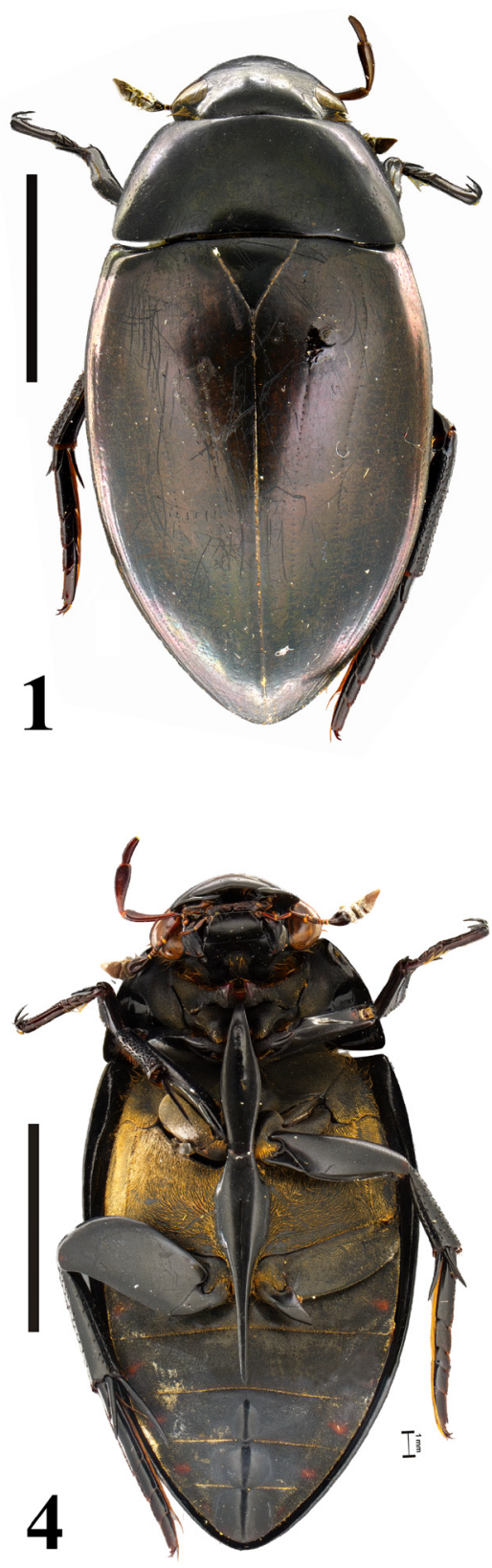
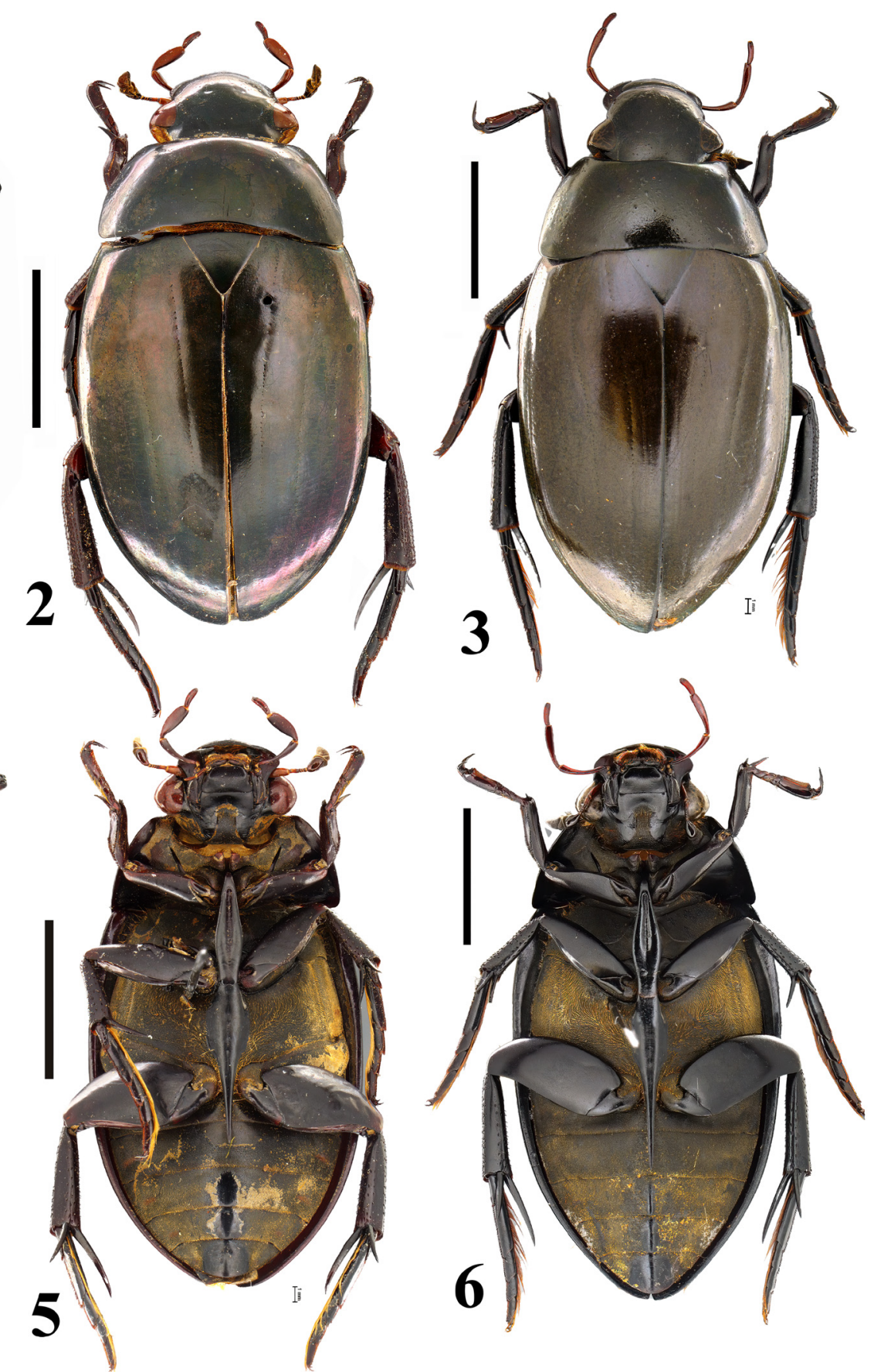

FIGURES 1-6. Dorsal and ventral view of Hydrophilus (Dibolocelus) spp. 1-2 H. (D.) ovatus Gemminger \& Harold; 3-4 H. (D.) pseudovatus sp. nov.; 5-6 H. (D.) nucleoensis sp. nov.

Thorax: Prosternal lobes raised and apically rounded, with short reddish-yellow setae at apex; mesoventrite with keel wide, with lateral margins rounded and convergent towards apex, with a broad and shallow concavity at basal half, deeper near apex; metaventrite with a broad, flat keel with a median longitudinal groove, ending as a long spine reaching the posterior margin of the second abdominal ventrite (Fig. 2). Elytra with four well-marked rows of small black spots, two on the disc, one sublateral starting after the humerus, and another one less complete on each side.

Legs: Anterior tibiae with internal spur short, flat, sub-rectangular with its truncated and straight apex, the longer external spur, acute sub-triangular; fifth protarsomere wide, and longer than the previous ones together. Tarsal claw long, curved and without a tooth in the base, internal claw little longer than the external. Protarsomeres 2-5 with tufts of golden setae in the outer edge (Fig. 8). 

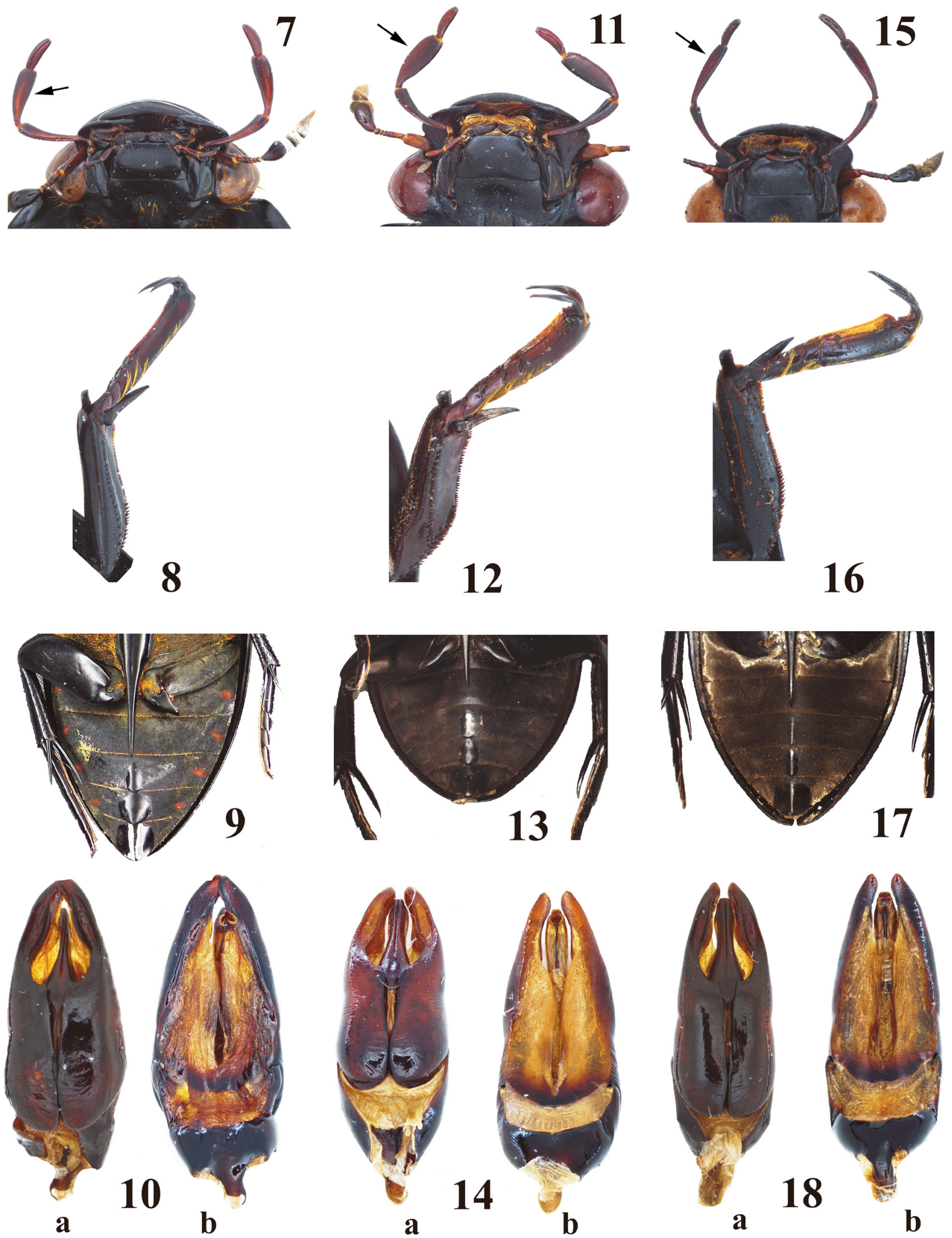

FIGURES 7-18. Morphological structures and male genitalia of Hydrophilus (Dibolocelus) spp. 7-10 H. (D.) ovatus Gemminger \& Harold; 7 ventral view of head (arrow: third labial palpomere); 8 protibia and tarsi, 9 ventral view of abdomen; 10a aedeagus ventral; 10b aedeagus dorsal; 11-14 H. (D.) pseudovatus sp. nov.; 11 ventral view of head(arrow: third labial palpomere); 12 protibia and tarsi, 13 ventral view of abdomen; 14a aedeagus ventral; 14b aedeagus dorsal; 15-18 H. (D.) nucleoensis sp. nov.; 15 ventral view of head (arrow: third labial palpomere); 16 protibia and tarsi, 17 ventral view of abdomen; 18a aedeagus ventral; $\mathbf{1 8 b}$ aedeagus dorsal. 
Abdomen: Vestiture leaving a wide, long, oval glabrous area at mid-line in ventrites 3-4; and a broader subrectangular one in ventrite 5. Ventrites 3 and 4 raised and flattened above, with apex slightly acute and projected on the next ventrites. All ventrites bearing a yellow-reddish oval spot on each side (Figs 2, 9).

Genitalia: Total length $5.4 \mathrm{~mm}$; phallobase long, (length: $2.7 \mathrm{~mm}$, width: $2 \mathrm{~mm}$ ), widest at union with parameres, manubrium slender with apex rounded. Parameres long $(3.95 \mathrm{~mm})$, very wide at basal 3/5, and elongated oval in their $2 / 5$ apical, with a wide and deep oval concavity not reaching apex, and with minute teeth in the internal margin at the apical half, getting more abundant apically. Median lobe slightly shorter than parameres $(3 \mathrm{~mm})$, wide, sub-triangular, with a longitudinal median groove, and apex rounded (Fig. $10 \mathrm{a}, \mathrm{b}$ ).

Sexual dimorphism. Female specimens are similar to males but with maxillary palpi narrow, tibiae with long sub-triangular spurs, tarsal claws curved and acute, with an acute basal tooth.

Distribution. The reported distribution of this species includes the United States of America, Southern Canada and Mexican states Chiapas, Michoacán, Nayarit, Quintana Roo, San Luis Potosí, Tamaulipas and Veracruz (Smetana 1988; Short \& McIntosh 2014) (Fig. 41). Nevertheless, in the present work we found no additional specimens from Mexico among the studied material and the description is based on specimens collected in USA.

Taxonomical comments. Andrew E.Z. Short (SEMC) (personal communication), noticed the existence of specimens from Veracruz of $H$. (D.) ovatus that show a certain degree of intergradation with $H$. (D.) pseudovatus sp. nov. in regards to the protarsomeres of males where the articles are slightly flattened, although not completely forming a laminar expansion as in the new species. Extensive additional sampling in Mexico and analysis of the genetic information of these population is needed in order to better elucidate the status of these two species.

\section{Hydrophilus (Dibolocelus) pseudovatus Arce-Pérez \& Arriaga-Varela sp. nov.}

Figs. 3, 4; 11-14, 41.

Etymology. Named $H$. (D.) pseudovatus (ancient Greek pseudes = false) in recognition of the external resemblance of this species to $H$. (D.) ovatus.

Type material $\left(\mathbf{2 5}{ }^{\Uparrow}, \mathbf{1 4}+\right.$ ). Holotype male: MEXICO: Nayarit, San Blas, Matanchén, 80 m, 26.vii.2007,

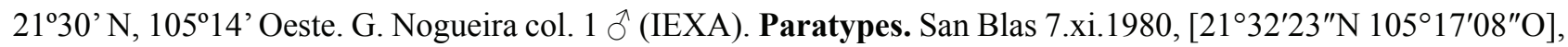

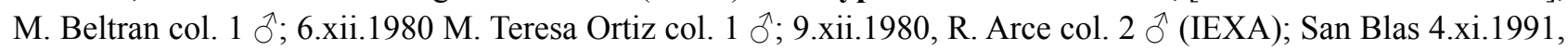

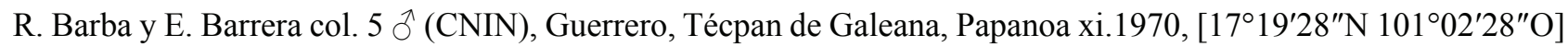

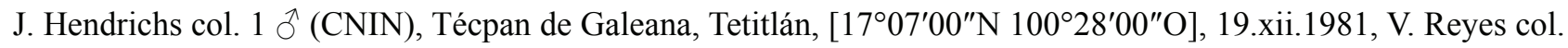

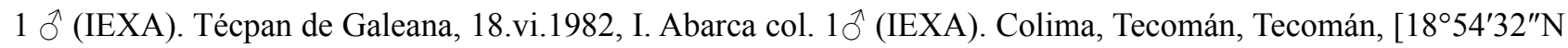
10352'29"O], xi.1970, 4 ${ }^{\circ}, 5$ (INIFAP-Celaya). Jalisco, Tomatlán, presa Cajón de Peñas, La Quebrada, BTC, 100 m, [1956'3" N, 105¹4'8" O], 12.x.1996, J. C. Rodríguez col. 1 ô (CZUG); Punta Pérula, [19³6'18" N, 1059'30" W, 28.x.1999, L. G. Martínez col. 1 q (CZUG); Punta Pérula, [19³7'27.1" N, 1057'34.4" W, a la luz, 11.xi.1999, H.

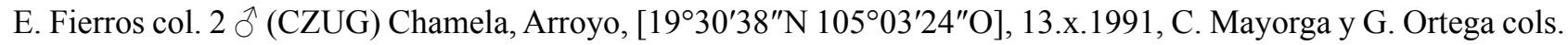

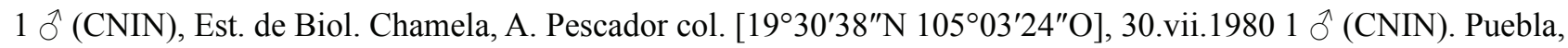

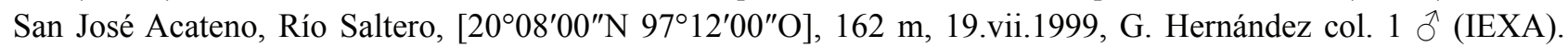

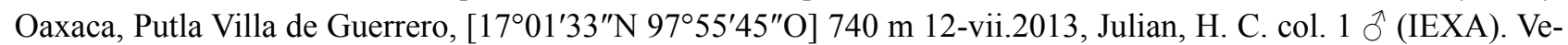
racruz, Alto Lucero, 5 km. Norte de Palma Sola, 19¹0'51" N Longitud: 96 08'34" O, 22.iv.1990, Luz Mercurial, F.

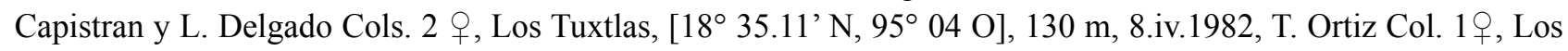

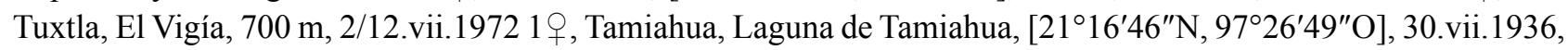

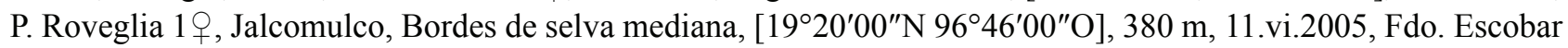

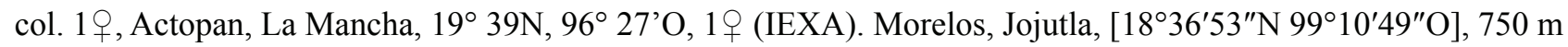
, 1 ? ? (CNIN).

Diagnosis. The specimens of $H$. (D.) pseudovatus sp. nov. are very similar to those of $H$. (D.) ovatus from North America. The new species can be distinguished from $H$. (D.) ovatus because [the characters of $H$. (D.) ovatus are provided in brackets for comparative purposes the characters of $H$. $(D$.) ovatus] third maxillary palpomere shorter and wider, curved towards apex, markedly flattened and broadened toward the apex, with $0.085 \mathrm{~mm}$ in its side wider (Fig. 7) [third maxillary palpomere slightly flattened and broadened towards its apex, with its internal margin slightly convex (near $0.80 \mathrm{~mm}$ in its widest part) (Fig. 11)]; the fifth protarsomere shorter than basal tarsomeres together, flat and with a slight but evident internal laminar expansion (Fig. 12) [fifth protarsomere is long 
and wide, longer than the basal tarsomeres together, no internal expansion (Fig. 8)]; the metaventral spine shorter, not exceeding $3 / 4$ of the second abdominal ventrite (Figs. 4, 13) [metaventral spine longer, reaches or exceeds the posterior margin of the second abdominal ventrite (Figs. 2, 9)]; ventrites 3 and 4 slightly raised, with their apical margin slightly rounded and very slightly projecting over the following ventrite (Fig. 13) [ventrites 3 and 4 raised, with their apical margin slightly acute and slightly projecting over the next ventrite (Fig. 9)]; abdominal ventrites without evident yellowish-reddish lateral oval spots [ventrites with evident yellowish-reddish lateral oval spots]; median lobe broad (Fig. 14) [narrower in H. (D.) ovatus (Fig. 10)].

Description male holotype. Body elongated-fusiform, length 32-36 mm (male holotype: $35 \mathrm{~mm}$ ), width 17$17.5 \mathrm{~mm}$ at humeri (Holotype: $17 \mathrm{~mm}$ ), $2 \times$ longer than wide, dorsally strongly convex and glabrous, ventrally flat and pubescent; dorsal color black with dark green tone; ventrally black with reddish yellowish hue, ventral vestiture pale yellow; antennae, palpi and legs dark-reddish (Figs 3, 4).

Head: Antennae short with nine antennomeres, scape large and robust, longer than the next four antennomeres together, pedicel subequal to the following three antennomeres, sixth antennomeres long and oval, subequal to the previous four together, not covering the first article of antennal club (Fig. 11). Maxillary palpi long and slender, with four palpomeres, with lengths: 0.04, 0.29, 0.27, $0.14 \mathrm{~mm}$; first palpomere small, sub-conical, second long, curved, slightly broadened towards apex, third shorter and wider, curved towards apex, markedly flattened toward the apex, with $0.085 \mathrm{~mm}$ in its side wider, fourth short, oval, with truncated. Mentum hexagonal, $1.7 \times$ wider at base than long, lateral margins parallel at basal half, apically converging straightly, apex truncated and straight. Labial palpi short, length of palpomeres: 0.02, 0.09, $0.06 \mathrm{~mm}$; first palpomere small and broad, second long and slightly broadened towards apex, $1.5 \times$ longer than the third, with short golden setae near the internal marginapex, third palpomere short and oval, with apex rounded (Fig. 11).

Thorax: Prosternal lobes raised and apically rounded, with short reddish-yellow setae at apex; mesoventrite with keel long and narrow, with lateral margins rounded and convergent towards apex, with a broad and shallow concavity at basal $3 / 5$, deeper near apex. Metaventrite with keel wide and flat, with feeble median longitudinal groove, ending as a long spine reaching half-length of the second abdominal ventrite (Fig. 4). Elytra with four wellmarked rows of black spots, two on the disc, one sublateral starting after the humerus, and other more incomplete on the sides (Fig. 3).

Legs: Anterior tibiae with two spurs; internal one shortest, flat, sub-rectangular with apex truncate straight, with a small notch close to the external margin; external spur longer, sub-triangular, acute; fifth protarsomere shorter than the previous ones together, broadly flattened, with a small but evident internal laminar expansion; tarsal claws curved, without basal tooth, internal claw slightly longer than external one, protarsomeres $2-5$ with tufts of golden setae in the external margin (Fig. 12).

Abdomen: Vestiture leaving a wide and long glabrous oval area at mid-line in ventrites 3-4; and a broader subrectangular one in ventrite 5 . Ventrites 3 and 4 raised and flattened above, with apex rounded and slightly projected on the next ventrites (Figs 4, 13).

Genitalia: Total length $6.0 \mathrm{~mm}$; phallobase long (length: $2.9 \mathrm{~mm}$ width $2.1 \mathrm{~mm}$ ) narrow with apex of manubrium rounded; parameres long (length: $4.1 \mathrm{~mm}$ ), broadened at basal 3/5, elongated-oval at apical 2/5, with a deep oval concavity not reaching the apex, with minute teeth in the internal margin at the apical half, getting more abundant apically. Median lobe slightly shorter than the parameres $(3.7 \mathrm{~mm})$, broad sub-triangular with rounded apex, with a median sulcus, apex rounded (Fig. $14 \mathrm{a}, \mathrm{b}$ ).

Sexual dimorphism. Females similar to males but with palpi more slender, anterior tibiae with spurs elongate sub-triangular, tarsal claw long, curved and acute, with a basal acute tooth.

Variation. Body length 32-36 mm, humeral width 17.0-17.5, 18-2.0× longer than wide; coloration can be brown-reddish (in old specimens); sixth antennomere and antennal club can be reddish-yellow to dark red; average length of maxillary palpomeres: $0.04,0.29,0.26,0.15 \mathrm{~mm}$; average width third palpomere: $0.085 \mathrm{~mm}$; average length of labial palpi: $1.8 \mathrm{~mm}$; prosternal lobes with apex rounded to acute; internal spur of protibiae with apex truncate, sometimes without notch in the external margin.

Distribution. Mexico: Colima, Guerrero, Jalisco, Morelos, Nayarit, Oaxaca, Puebla, Veracruz (Fig. 41).

Taxonomic comments. Since this species differs from $H$. (D.) ovatus in characters of key taxonomic importance like the shape of male maxillary palps, the protarsal structure and the male genitalia we consider that these differences support the description of $H$. (D.) pseudovatus as a new species. However, both species seem to share a large part of its distribution in Mexico (Fig. 41). Furthermore, according to Andrew E.Z. Short (personal com- 
munication) some $H$. (D.) ovatus specimens from Veracruz, Mexico are somewhat intermediate in morphology with $H$. (D.) pseudovatus sp. nov. In order to fully elucidate the nature of the relation between these two species more sampling in Mexico is needed as well as to study their genetic information.

\section{Hydrophilus (Dibolocelus) nucleoensis Arce-Pérez \& Arriaga-Varela sp. nov.}

Figs. 5, 6; 15-18, 42

Etymology. This new species is named $H$. (D.) nucleoensis because of its distribution on the Central American Nucleus, a natural area formed by mountain ranges that go from the center-south of the state of Chiapas in Mexico to the north of Nicaragua (see Halffter 1987; Halffter \& Morrone 2017).

Type material (31 ${ }^{\wedge}, 28$ ). Holotype male: MEXICO: Chiapas: Reserva Montes Azules $\left[16^{\circ} 50^{\prime} 00^{\prime \prime} \mathrm{N}\right.$

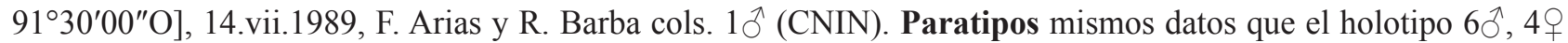

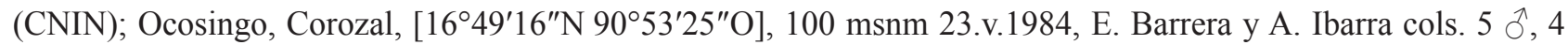

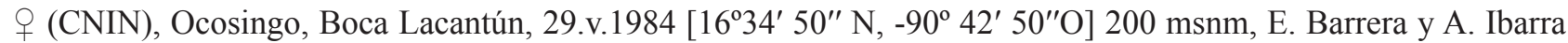
cols. 2 ○, 2 ( (CNIN); 24.v.1984, E. Barrera, A. Ibarra y M. Garcia cols. 1 ô, 1 + (CNIN); 24.v.1984, A. Ibarra col.

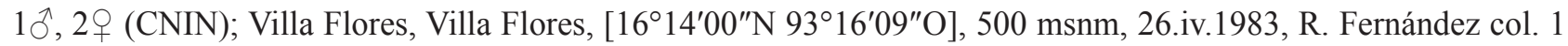
O̊, 4.x.1983, E. Ríos col. 1 ô, 19.x.1983, J. Melchor 1 q, 8.xi.1983, S. Serrano col. 1 q, 13.xi.1983, C.A. col. 1 q 3vii.1990, G. Morales col. 1 đ̊, 20.x.1999, Benjamin C. col . 19, Copainala, Copainala, $17^{\circ} 06^{\prime}$ norte, $93^{\circ} 17^{\prime}$ Oeste, 440 msnm, 16.v.1997, Arroyo, C.I. Sánchez col. 1 q (IEXA); Palenque, 19.v.1984, [17³0'33"N 9158'56"O], 60 msnm, A. Ibarra y M. García cols. 1 (CNIN); Palenque Malla Bell, 20.iv.1988, J. Kemner col. 1 \& (IEXA),

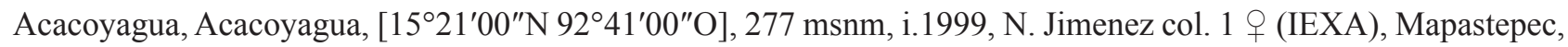

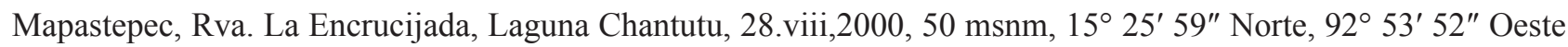

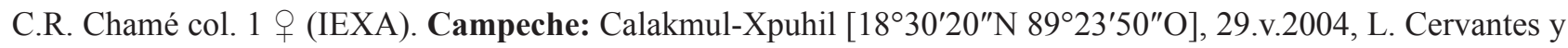
C. Mayorga cols. 1 Oै, 1 (IEXA), Calakmul-Xpuhil, 200 msnm, 15/17.xi.2001, E. Barrera y H. Brailovsky cols. $1 q$ (CNIN); Calakmul, 24.vii.2014, Selva Alta Perenifolia, Fernando Escobar col. 1 đิ (IEXA); Guerrero: Hwy 200, 5 mi. S. Tecpan, $17^{\circ} 11.2^{\prime} \mathrm{N}, 10036.7^{\prime \prime} \mathrm{W}, 30 \mathrm{~m}, 20 . v i .2010$, D.Brzoska $1 \hat{\jmath}$ (SEMC). GUATEMALA. Escuintla: San

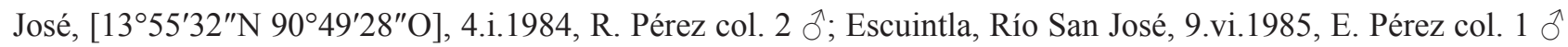
(UVGC); Petén, San José, October 1991, leg. Frisch, 1 đ̊ (SEMC). NICARAGUA: Rio San Juan: Los Guatusos,

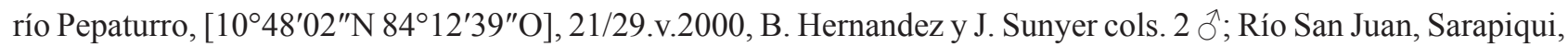
1/5.ix.2006, A. Borges y P. Andino cols. 1 क; San Juan, San Carlos, 20.ii.1995, F. Collantes col. 1 + (IEXA). COS-

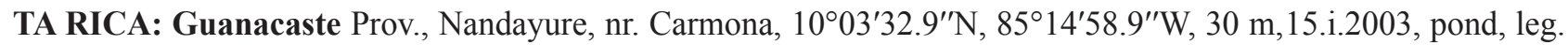
Short, Roughley, \& Porras 1 J, 1 ( (SEMC, INBio); Guanacaste Prov, Rd to Palo Verde, roadside ditch, 11.i2004, leg. Short \& Lebbin,AS-04-027, 1 § (SEMC); Limon Prov., Sector Cedrales de la Rita, 3 km N. Del Puente Rio Suerte, RutaPuerto Lindo, November 1995, leg. E. Rojas, INBIO-CRI002-378269, 1 ठ (INBio).

Diagnosis. This species can be distinguished by the following combination of characters: Maxillary palpi clearly long and slender; fifth protarsomere as long as the basal ones together, flattened, with evident internal laminar expansion. This species is very similar to $H$. (D.) ovatus and $H$. (D.) pseudovatus sp. nov. but can be distinguished from them by [the characters the characters of $H$. (D.) ovatus and $H$. (D.) pseudovatus are provided in brackets for comparative purposes] the maxillary palpi clearly longer and slender, width of the third palpomere 0.065 (Fig. 15) $[H$. (D.) ovatus and $H$. (D.) pseudovatus sp. nov. present maxillary palpi with the third palpomere flattened and widened, with width greater than $0.080 \mathrm{~mm}$ (Figs. 7,11)], fifth protarsomere flat and with evident internal laminar expansion (Fig. 16) [without or with slight internal laminar expansion (Figs. 8, 12)], abdominal ventrites 3 and 4 with slender glabrous area at midline (Fig. 17) [ventrites 3 and 4 with wide glabrous area at mid-line (Figs. 9, 13)], abdominal ventrites 3 and 4 raised and slightly acute above at midline (Fig. 17) [abdominal ventrites 3 and 4 raised and flat above at midline (Figs. 9, 13)]; H. (D.) ovatus and H. (D.) pseudovatus are mainly distributed in the Neartic portion of Mexico while $H$. (D.) nucleoensis sp. nov. is mainly distributed in the Neotropical part of Mexico, extending towards Central America in Guatemala and Nicaragua (Fig. 42).

Description male holotype. Body elongated-fusiform, length 32-37 mm (male holotype: $36 \mathrm{~mm}$ ), width 17.0$17.5 \mathrm{~mm}$ at humeri (holotype: $17.0 \mathrm{~mm}$ ), $2.1 \times$ longer than wide, dorsally strongly convex and glabrous, ventrally flat and pubescent; dorsal color black with dark green hue; ventrally black with reddish hue, ventral vestiture pale yellow; antennae, palpi and legs black with reddish hue (Figs 5,6). 
Head: Antennae short with nine antennomeres, scape large and robust, longer than the next four antennomeres together, pedicel subequal to the following three antennomeres, sixth antennomere long and oval, subequal to the previous four together, not covering the first article of antennal club (Fig. 15). Maxillary palpi long and slender, with four palpomeres, with lengths: 4.0, 3.1, 2.8, $1.6 \mathrm{~mm}$; first palpomere small, sub-conical, second long, curved, slightly broadened towards apex, third shorter and wider, slightly flattened towards apex, with $0.060 \mathrm{~mm}$ in its wider side, fourth short, oval, with truncated apex. Mentum hexagonal, $1.7 \times$ wider at base than long, lateral margins parallel at basal half, apically converging straightly, apex truncated and straight. Labial palpi short, length of palpomeres: $0.02,0.09,0.06 \mathrm{~mm}$; first palpomere very small and subconical, second long and slightly broadened towards apex, $1.2 \times$ longer than the third, with short golden setae near the internal margin, third palpomere short and oval, with apex rounded (Fig. 15).

Thorax: Prosternal lobes raised and apically rounded, with short reddish-yellow setae at apex; mesoventrite with broad keel, with lateral margins rounded and convergent towards apex, with a broad and shallow concavity at basal half, deeper towards apex. Metaventrite with keel wide and flat, with feeble median longitudinal groove, ending as a long spine reaching half-length of the second abdominal ventrite (Fig. 6). Each elytron with two well-marked rows of black spots, one sublateral starting after the humerus, and other more incomplete on the sides (Fig. 5).

Legs: Anterior tibiae with two spurs; internal one shortest, flat, sub-rectangular with apex truncate straight; external spur longer, sub-triangular, acute; fifth protarsomere as long as the basal ones together, flattened, with evident internal laminar expansion; tarsal claws curved, without basal tooth, internal claw slightly longer than external one, protarsomeres 2-5 with tufts of golden setae in the external margin (Fig. 16).

Abdomen: Vestiture leaving a long oval glabrous area at mid-line in ventrites 3-4; and a broader sub-rectangular one in ventrite 5 . Ventrites 3 and 4 raised and slightly acute above, with apex slightly rounded and projected on the next ventrites. (Figs 6,17 ); ventrite 5 raised and slightly sharp above.

Genitalia: Total length $6.05 \mathrm{~mm}$; phallobase long (length: $2.85 \mathrm{~mm}$, width $2.25 \mathrm{~mm}$ ) narrow with apex of manubrium rounded; parameres long (length: $4.25 \mathrm{~mm}$ ), distinctly broadened at basal 3/5, elongated-oval at apical 2/5, with a deep oval concavity not reaching the apex, with minute teeth in the internal margin at the apical half, getting more abundant apically. Median lobe slightly shorter than the parameres $(3.75 \mathrm{~mm})$, broad sub-triangular, with a median sulcus, apex rounded (Fig. 18 a, b).

Sexual dimorphism. Females similar to males but with narrow maxillary palpi, anterior tibiae with long subtriangular spurs, tarsal claws curved and acute, with and basal acute tooth.

Variation. Body length between 32-37 mm, width 17.0-17.5 mm, 1.8-2.0× longer than wide; body color can be dark brown with yellow-reddish hue (in old specimens); average length of maxillary palpomeres: 4.0, 3.0, 2.9 and $1.6 \mathrm{~mm}$; average width of third maxillary palpomere: $0.65 \mathrm{~mm}$; total length of labial palp: $1.8 \mathrm{~mm}$.

Distribution. Mexico: Campeche, Chiapas, Guatemala: Escuintla and Nicaragua: Río San Juan (Fig. 42).

\section{Hydrophilus (Dibolocelus) violaceonitens Jacquelin du Val, 1857 status restored}

Figs. 19, 20; 25-28, 37-40, 43, 46-49.

Hydrophilus violaceo-nitens Jacquelin du Val, 1857: 49.

Stethoxus (Dibolocelus) violaceonitens (Jacquelin du Val); Bedel, 1891: 314.

Hydrous (Dibolocelus) violaceonitens (Jacquelin du Val); Kuwert, 1893: 83.

Hydrophilus (Dibolocelus) smaragdinus Brullé. Syn.: Régimbart, 1901: 227.

Hydrophilus (Dibolocelus) smaragdinus Brullé (in part), Hansen, 1999: 162.

Type material. [Studied through photographs] Female? holotype, MNHN: "Cuba / C. Chevrolat", "Type" , "Hydrophilus / violaceo-nitens", "smaragdinus Br. / v. violaceo nitens Duv." , "MUSÉUM PARIS / 1922 / coll. L. Bedel", "HOLOTYPE", "HOLOTYPE/ Hydrophilus / violaceonitens Jacquelin du / Val, 1857" / "MNHN, Paris/ EC11750/ [barcode]". [Specimen is damaged; maxillary palpi, mesotarsi and left metatarsus are missing]

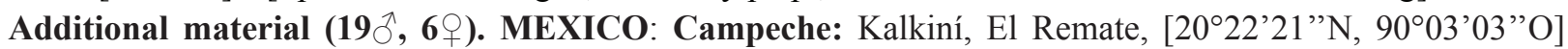
26.iv.1982, M. García col. 3ð^, 2 (CNIN); El Remate, entre raíces de manglar, 12.xii. 2020, S. Ospina col. $1{ }^{\lambda}$

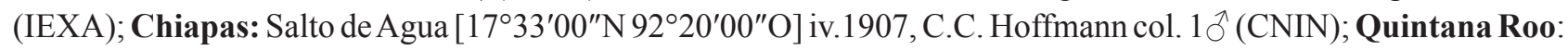

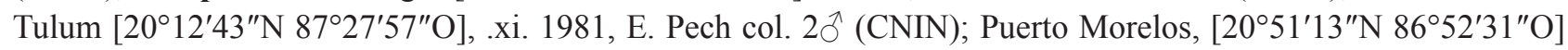
Gasolinera, 10.vii.1983, O. Canul col. $2{ }^{\Uparrow} 1$ ㅇ (CNIN); El Naranjo, Selva alta, 7.vii.1985, A. Cadena y Conde 
cols. Noct. 1 ㅇ (IEXA); F. Carrillo Puerto, $\left[19^{\circ} 34^{\prime} 43^{\prime \prime N} 88^{\circ} 02^{\prime} 43^{\prime \prime O}\right]$ Laguna Chunyaxche, 30.viii.1988, Fernán-

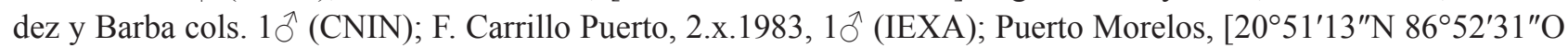

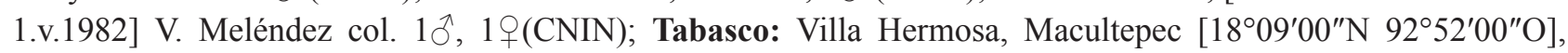

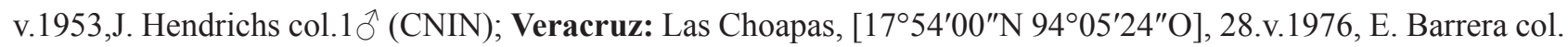

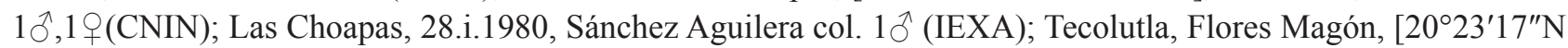

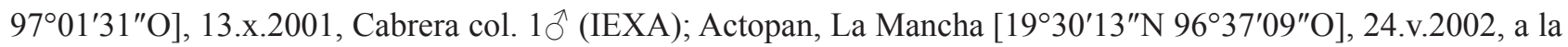

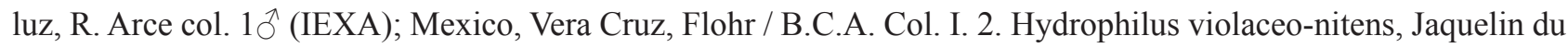
Val $2 \widehat{o}$ (BMNH). CUBA: Provincia Matanzas, Playa Girón, Martin Vyklicky leg. 19.v.2004 1ठิ (NMPC).
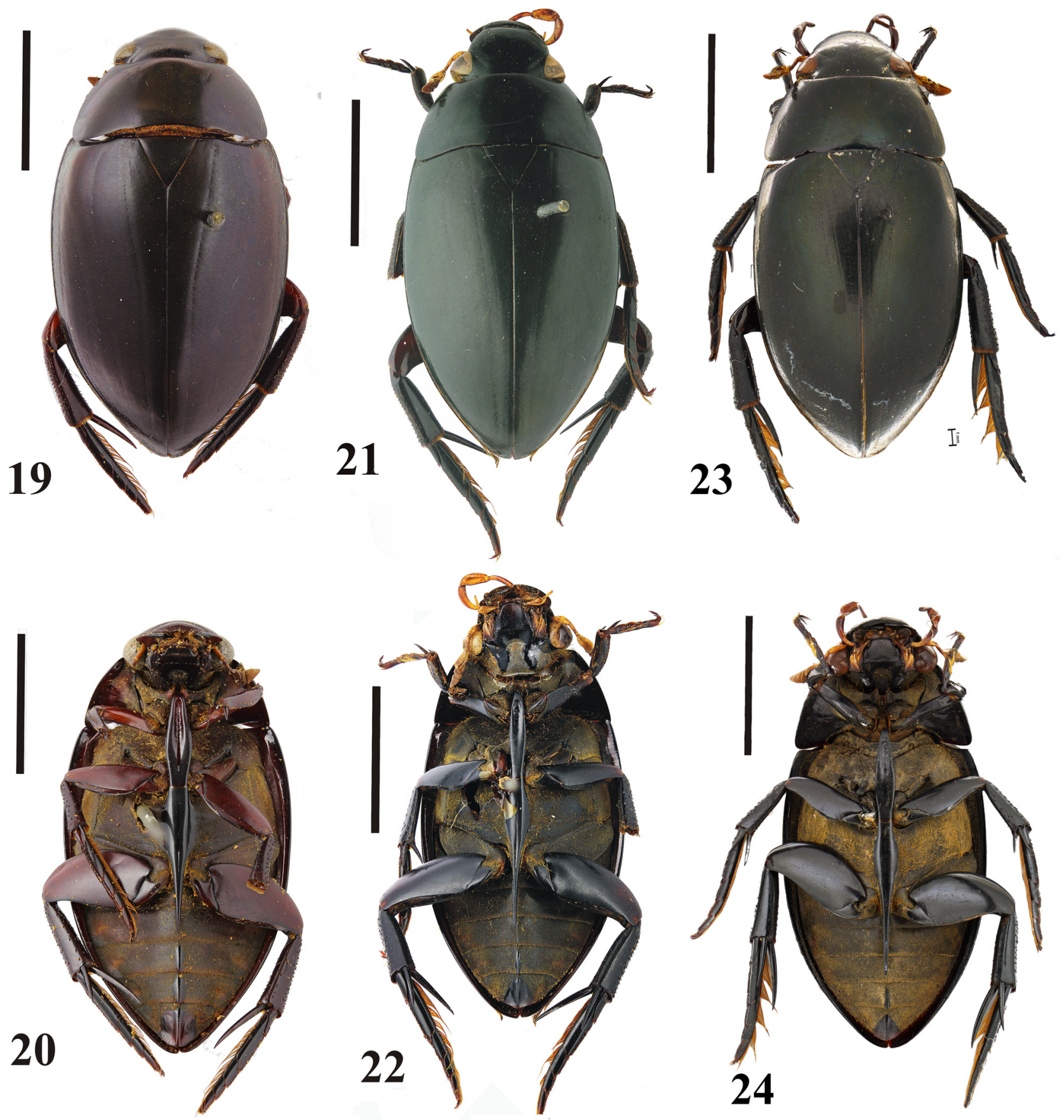

FIGURES 19-24. Dorsal and ventral view of Hydrophilus (Dibolocelus) spp. 19-20 H. (D.) violaceonitens status restored; 21-22 H. (D.) pollens Sharp; 23-24 H. (D.) cf. purpurascens (Régimbart). 

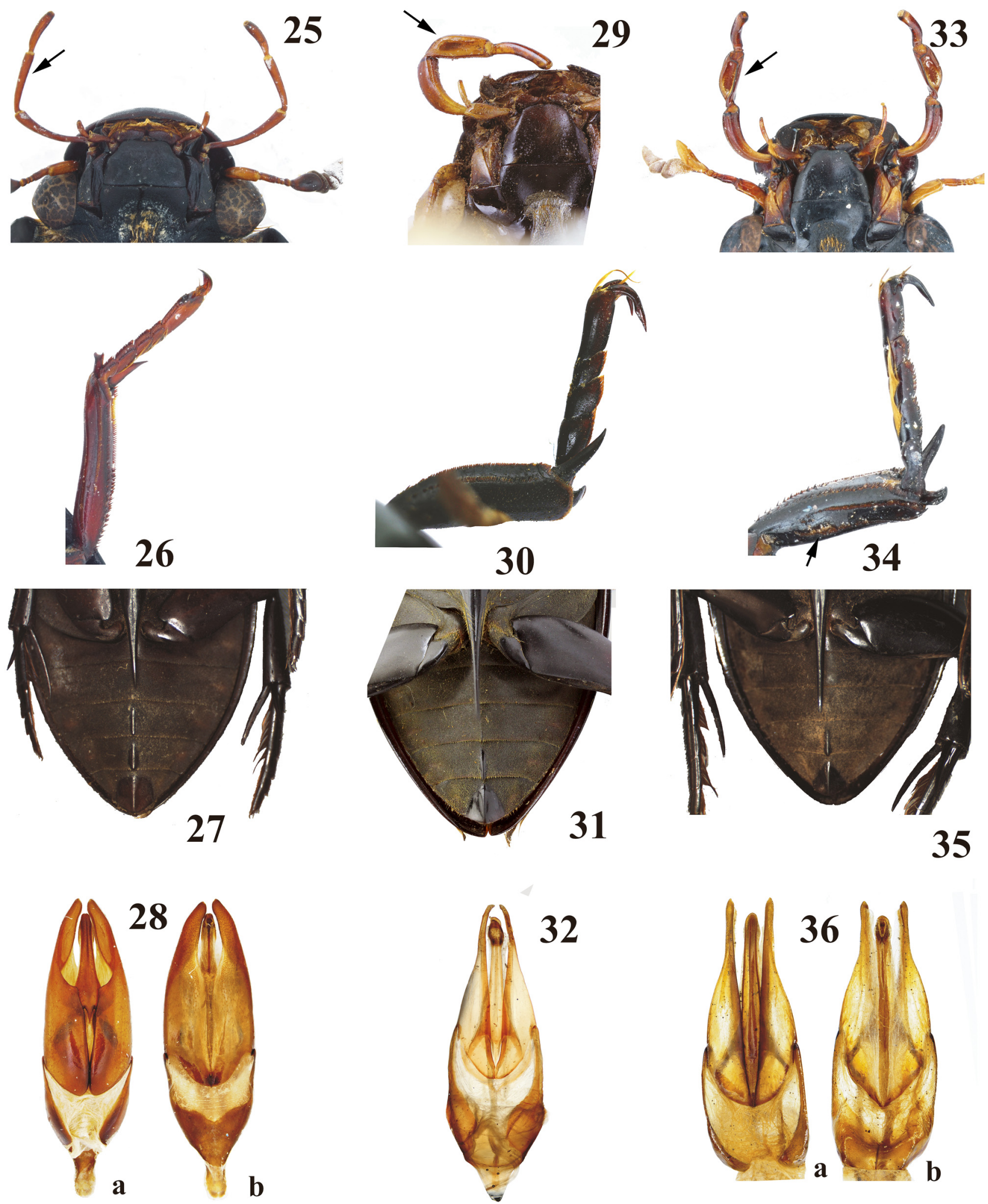

FIGURES 25-36. Morphological structures and male genitalia of Hydrophilus (Dibolocelus) spp. 25-28 H. (D.) violaceonitens sp. nov.; 25 ventral view of head (arrow: third labial palpomere); 26 protibia and tarsi, 27 ventral view of abdomen; 28a aedeagus ventral; 28b aedeagus dorsal; 29-32 H. (D.) pollens Sharp; 29 ventral view of head (arrow: third labial palpomere); 30 protibia and tarsi, 31 ventral view of abdomen; 32 aedeagus ventral; 33-36 $H$. (D.) cf. purpurascens (Régimbart); 33 ventral view of head (arrow: third labial palpomere); 34 protibia and tarsi (arrow: subrectangular row of hard setae); 35 ventral view of abdomen; 36a aedeagus ventral; 36b aedeagus dorsal. 

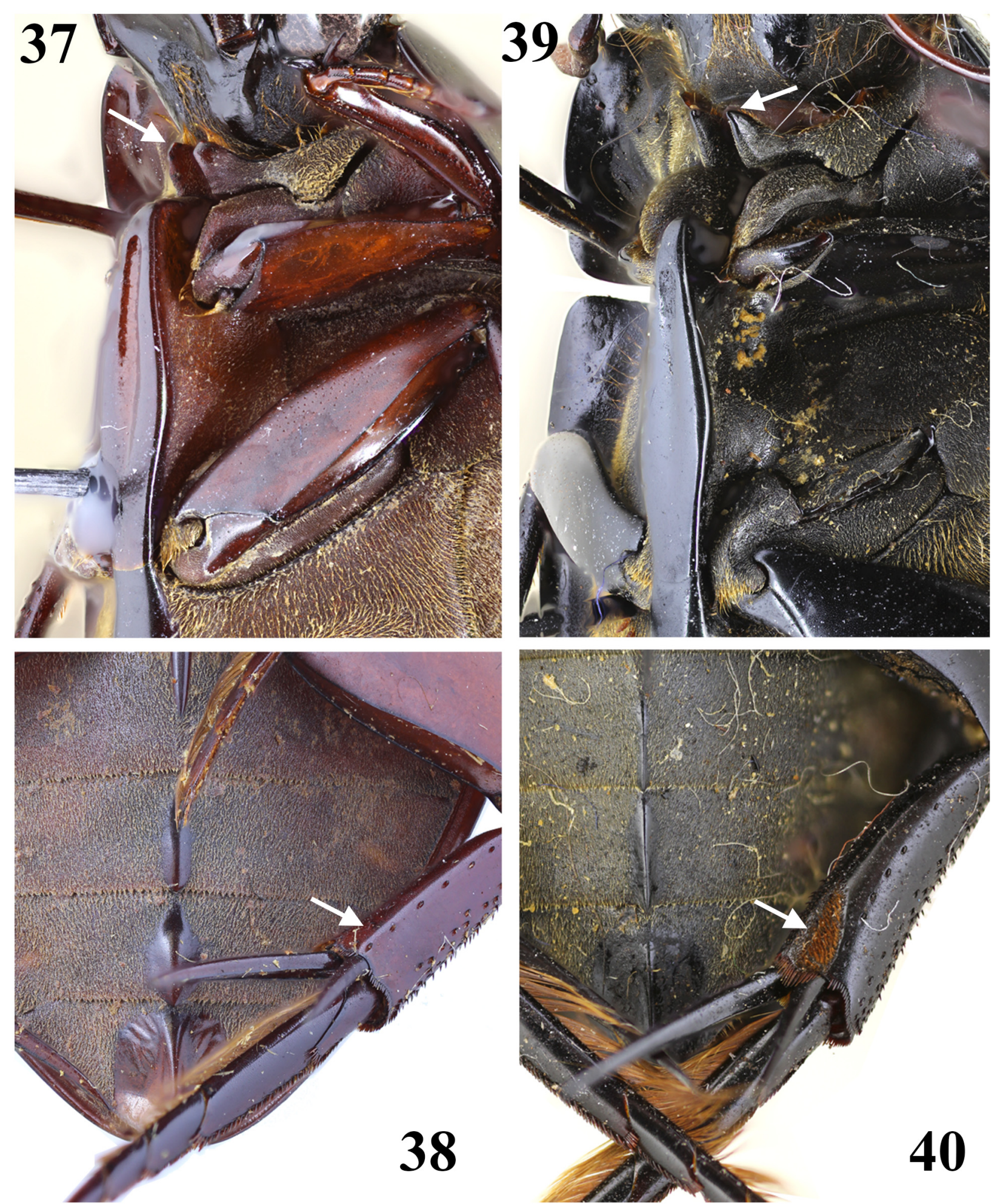

FIGURES 37-40. Comparison of morphology between $H$. (D.) violaceonitens and H. (D.) smaragdinus Brullé (from Brazil); 37-38 H. (D.) violaceonitens status restored; 37 ventro-lateral view of pro- and mesothorax (arrow: apically truncate prosternal lobes); 38 ventral view abdomen and hind tibia (arrow: tibial apex without patch of setae); 39-40 H. (D.) smardagdinus Brullé (from Brazil); 39 ventro-lateral view of pro- and mesothorax (arrow: acute apex of prosternal lobes); 40 ventral view abdomen and hind tibia (arrow: patch of setae in tibial apex).

Diagnosis. This species can be distinguished by the following combination of characters: Maxillary palpi long and narrow; anterior tibiae with internal spur sub-rectangular with bifid apex; fifth protarsomere shorter than basal ones together, without internal projection or expansion. This species can be distinguished from $H$. (D.) smaragdinus 
Brullé a species from South America with which it was synonymized until now, by [characters of $H$. $(D$.) smaragdinus provided in brackets for comparative purposes]: $H$. (D.) violaceonitens without setose patch in the apical region of hind tibiae of males (Fig. 38) [H. (D.) smaragdinus has a dense patch of short setae in the medial apical region of the posterior tibiae in males (Fig. 40)]; prosternal lobe sharply truncated apically (Fig.37) [prosternal lobes apically acute (Fig 39)]; ventrites 3-5 raised but not forming a sharp keel (Figs. 20, 27), [ventrites 3-5 raised as a sharp keel]; fifth protarsomere with straight internal margin and with reduced number of suction cups (Fig. 26) [fifth protarsomere wide with rounded internal margin, and with numerous suction cups]; male genitalia wide, parameres broad, abruptly narrowed towards apexapically, with a long internal oval concavity in the apical third, and with subapical elongated-oval gonopore (Fig. 28 a, b) [male genitalia slender with narrow parameres gradually tapering towards apex, and apex slightly widened]. Additionally, among the Mexican species $H$. (D.) violaceonitens is externally more similar to $H$. (D.) nucleoensis sp. nov., but differs from it by [the characters of $H$. (D.) nucleoensis provided in square brackets for comparative purposes]: in $H$. (D.) violaceonitens the mentum is broad, with parallel lateral margins in the basal half and in the apical half markedly curved, the apical margin truncated and slightly concave (Fig. 25) [mentum not wide, with lateral margins parallel and slightly curved in the basal half, apically markedly convergent, the apical margin truncated and straight (Fig. 15)]; fifth protarsomer shorter than the previous ones together and without internal projection (Fig. 26) [fifth protarsomer as long as the previous ones together, flat and with an evident internal laminar expansion (Fig. 16)]; anterior tibiae with sub-rectangular internal spur with bifid apex (Fig. 26) [anterior tibiae with sub-rectangular internal spur with straight and truncated apex (Fig. 16)].

Redescription. Body elongated-fusiform, length $33 \mathrm{~mm}$, width $17 \mathrm{~mm}$ at humeri, $1.9 \times$ longer than wide, dorsally strongly convex and glabrous, ventrally flat and pubescent; dorsal color black with dark green hue; ventrally black with reddish hue, ventral vestiture reddish yellow; antennae and palpi reddish yellow, legs black with reddish hue (Figs 19, 20).

Head: Antennae short with scape large and robust, longer than the next four antennomeres together, pedicel subequal to the following three antennomeres together, sixth antennomere long and oval, subequal to the previous four together, not covering the first article of antennal club. Maxillary palpi long and slender, with four palpomeres with lengths: 3.0, 2.8, 2.0, $1.5 \mathrm{~mm}$; first palpomere small, sub-conical, second long, curved, slightly broadened towards apex, third similar to the previous one but shorter, fourth short, oval, with truncated apex. Mentum hexagonal, $2 \times$ wider at base than long, lateral margins parallel at basal half, apically markedly curved, apex truncated and slightly concave. Labial palpi short, length of palpomeres: $0.2,0.8,0.6 \mathrm{~mm}$; first palpomere very small and subconical, second long and slightly broadened towards apex, $1.3 \times$ longer than the third, with short golden setae near the internal apex, third palpomere short and oval, with apex rounded (Fig. 25).

Thorax: Prosternal lobes raised and apically obtusely truncate, with long reddish-yellow setae at anterior margin of apex (Fig. 37); mesoventrite with broad keel, with lateral margins rounded and convergent towards apex, with a deep oval concavity at basal half, deeper towards apex (Fig. 37) and with transverse striae. Metaventrite with keel wide and flat, with feeble median longitudinal groove, ending as a short spine reaching $3 / 4$ of the second abdominal ventrite (Fig. 20). Each elytron with two well-marked rows of black spots, one sublateral starting after the humerus, and other incomplete on the sides (Fig. 19).

Legs: Anterior tibiae with internal spur shortest, flat, sub-rectangular with apex bifid, external spur longer, sub-triangular, acute; fifth protarsomere shorter than basal ones together, without projections, tarsal claws curved, without basal tooth, internal claw slightly longer than external one, all protarsomeres with tufts of golden setae in the external margin, fifth protarsomere bearing a small apical ventral spine (Fig. 26), hind tibia without setose patch (Fig. 38).

Abdomen: Vestiture leaving a slender and long glabrous oval area at mid-line in ventrites 3-4; and a broader sub-rectangular one in ventrite 5 . Ventrites 3 and 4 raised and slightly acute above, with its apex slightly acute and projecting over the next ventrite, ventrite 5 raised and subacute medially (Fig. 27).

Genitalia: Total length $5.2 \mathrm{~mm}$; phallobase long (length: 2.25 , width $1.85 \mathrm{~mm}$ ), narrow, with apex of manubrium rounded; parameres long (length: $4 \mathrm{~mm}$ ), broadened at basal 3/5, elongated-oval at apical 2/5, with a deep oval concavity not reaching the apex, with minute teeth in the internal margin at the apical half, getting more abundant apically; median lobe slightly shorter than the parameres $(3.7 \mathrm{~mm})$, broad sub-triangular, with a median sulci, apex rounded (Fig. 28a,b).

Sexual dimorphism. Females similar to males but with narrow maxillary palpi, anterior tibiae with long subtriangular spurs, tarsal claws curved and acute, with and basal acute tooth. 

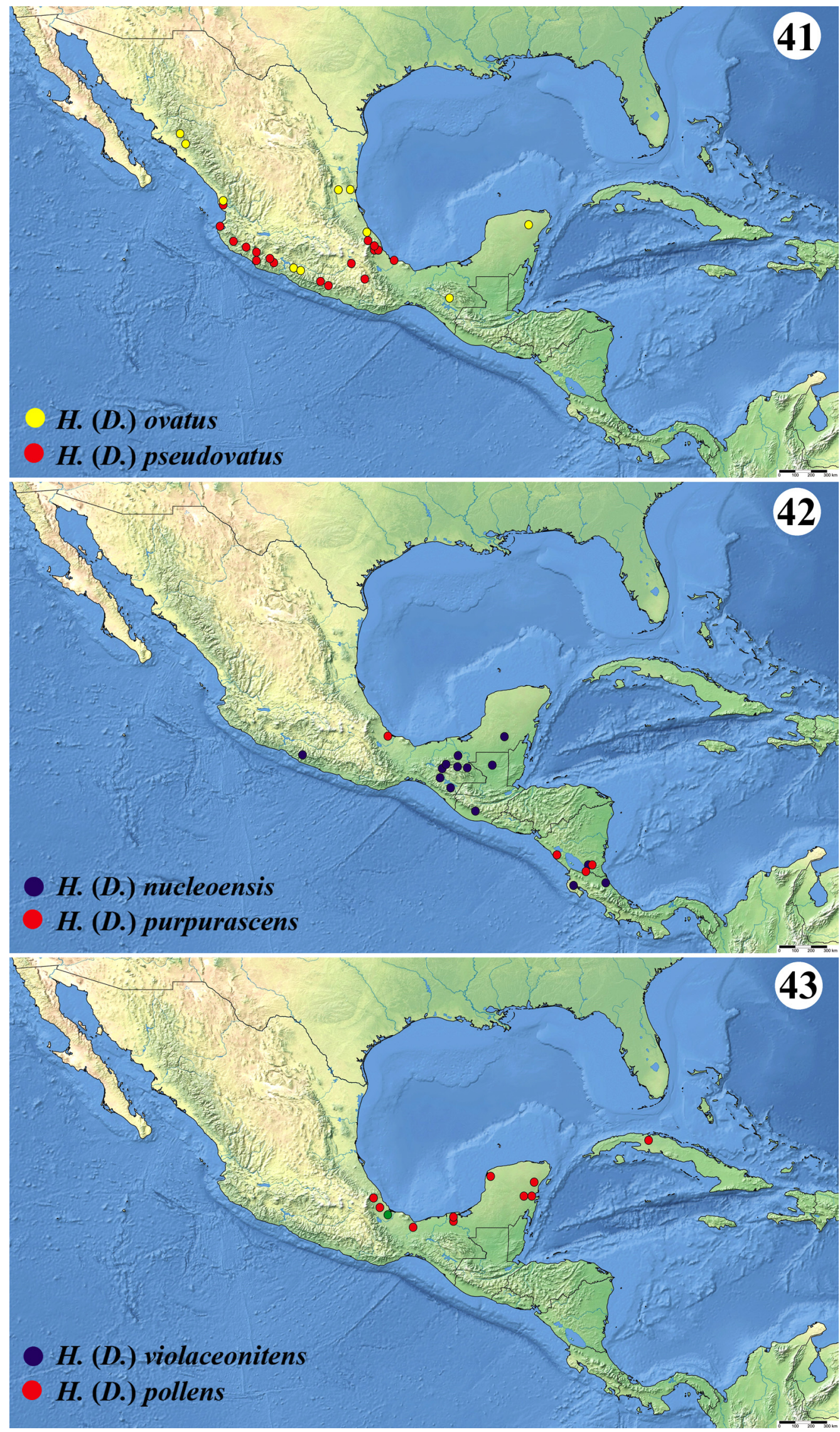

FIGURES 41-43 Geographical distribution of Hydrophilus (Dibolocelus) spp. in Mexico and Central America; 41 red circles: H. (D.) pseudovatus sp. nov., yellow circles: H. (D.) ovatus Gemminger \& Harold; 42 blue circles: H. (D.) nucleoensis sp. nov., red circles: H. (D.) cf. purpurascens (Régimbart); 43 red circles: H. (D.) violaceonitens, green circle: H. (D.) pollens Sharp. 


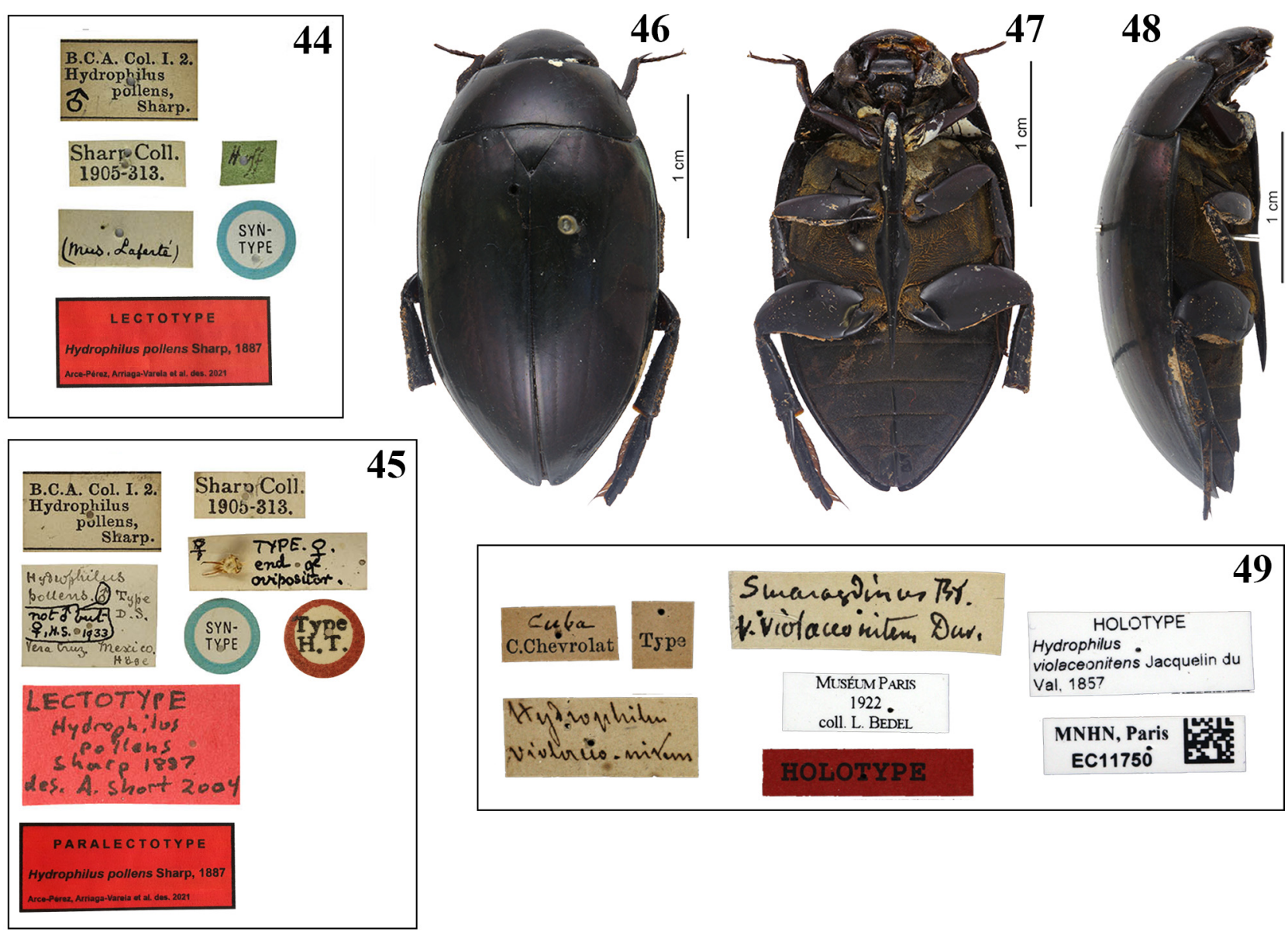

FIGURES 44-49. Type material and labels of Hydrophilus (Dibolocelus) from Mexico. 44 Specimen labels of Hydrophilus (Dibolocelus) pollens Sharp male lectotype (designated in this work); 45 Labels of female paralectotype; $46-\mathbf{4 8}$ Habitus of Hydrophilus (Dibolocelus) violaceonitens du Val; 46 dorsal; 47 ventral; 48 lateral; 49 Specimen labels of Hydrophilus (Dibolocelus) violaceonitens du Val holotype. Copyright of images 46-49 belongs to MNHN/Christophe Rivier.

Variation. Body length between $27-33 \mathrm{~mm}$, width $16.5-17.5 \mathrm{~mm}, 1.8-1.9 \times$ longer than wide; dorsal body color from dark greenish to black, ventral color can be dark reddish to black, sixth antennomere and antennal club from reddish yellow to pitch black; average length of maxillary palpomeres: 3.0, 2.7, 2.0 and $1.4 \mathrm{~mm}$; total length of labial palpi: $1.8 \mathrm{~mm}$.

Taxonomic comments. This species was originally described by Jacquelin du Val (1845) from Cuba, and later recorded in Mexico by Sharp (1887) based on two specimens from Veracruz. Later Régimbart (1901) synonymized it under $H$. (D.) smaragdinus Brullé a species described from South America. Currently $H$. (D.) smaragdinus is recorded from several countries in the Neotropical Region: Bolivia, Brazil, French Guiana, Peru, Venezuela, Cuba and Mexico (Bachmann 1968; Hansen 1999). Although, unfortunately we did not have the chance of directly studying the holotype deposited in Museum National d'historie Naturelle, Paris, we had access to high-definition photographs of the probably female holotype kindly provided by the curators of the museum (Figs 46-49). After its study and the thorough examination of the morphology of the specimens from Veracruz studied by Sharp, multiple other specimens from Mexico, one recently collected specimen from Cuba, and its comparison with specimens of H. (D.) smaragdinus from Brazil and Venezuela (AOBC, NMPC), identified by A.O. Bachmann and Martin Fikáček respectively (Figs 37-40), we conclude that the specimens from Cuba and Mexico are not conspecific with $H$. (D.) smaragdinus Brullé, therefore the restoration of $H$. (D.) violaceonitens as a valid species is fully justified. The present description of this species is based on a male from Mexico (Veracruz, La Choapas) compared to the material that Sharp (1887) cited from Veracruz and to a male specimens from Cuba (Matanzas, 10) and other specimens from Mexico.

Distribution. Cuba: Matanzas; Mexico: Campeche, Chiapas, Quintana Roo, Tabasco, Veracruz (Fig. 43) 


\section{Hydrophilus (Dibolocelus) pollens Sharp, 1887}

Figs. 21, 22; 29-32, 43.

Hydrophilus pollens Sharp, 1887: 762.

Dibolocelus pollens (Sharp); Régimbart, 1901b: 665.

Hydrous (Dibolocelus) pollens (Sharp); Zaitzev, 1908: 367.

Type material (1ð, 1 O): male lectotype, BMNH: B.C.A. Col. I. 2. Hydrophilus pollens, Sharp. / Sharp Coll. 1905313 / hoff / Mus. Laferté / Syntype / LECTOTYPE, Hydrophilus pollens Sharp, Arce-Pérez, Arriaga-Varela et al. Des. 2021; female paralectotype, BMNH: Hydrophillus pollens $\widehat{\delta}$ [not $\widehat{\phi}$ but + , H.S. 1933], Vera Cruz, Mexico. Höge / B.C.A. Col. I. 2. Hydrophilus pollens, Sharp. / [ovipositor in slide] + , TYPE 9 , end of ovipositor / Syntype / Type H.T, / LECTOTYPE Hydrophilus pollens Sharp 1887, des. A. Short, 2004 / PARALECTOTYPE, Hydrophilus pollens Sharp, Arce-Pérez, Arriaga-Varela et al. Des. 2021.

Diagnosis. This species can be distinguished by the following combination of characters: maxillary palpi robust, inflated, with third palpomere with a deep ventral excavation; anterior margin of mentum rounded. Fifth protarsomere shorter than basal ones together, without laminar expansion. Protarsal claws moderately long, curved, expanded at distal $2 / 5$, apex markedly acute. This species is very similar to $H$. $(D$.) $c f$. purpurascens, but can be distinguished by [the characters of $H$. $(D$.) cf. purpurascens are provided in square brackets for comparative purposes] H. (D.) pollens being dorsally black with greenish hue (Fig. 21) [dark green with purple reflections (Fig.23)]; anterior margin of mentum rounded (Fig. 29) [truncated and straight (Fig. 33)]; protarsal claws expanded to $2 / 5$ apical and apically acute (Fig. 30) [claws not expanded, only acute (Fig. 34)]; the metaventral spine shorter, not exceeding 1/2 of the third abdominal ventrite (Fig. 22) [metaventral spine longer, reaches or exceeds the posterior margin of the third abdominal ventrite (Figs. 24)]; ventrites 3 to 5 with a sharp and glabrous crest (Fig. 31) [ventrites 4 and 5 with a thick and glabrous crest (Fig. 35)]; slender parameres, slightly directed inward and with their apex truncated and directed inward (Fig. 32) [parameres thick, slightly directed outward and with apex broad sub-triangular (Fig.36)].

Redescription. Body elongated-fusiform, length 34-39 mm, width $15-16 \mathrm{~mm}$ at humeri, $2.2-2.3 \times$ longer than wide, dorsally strongly convex and glabrous, ventrally flat and pubescent; dorsal color black with dark green tone, more evident under direct light; ventrally black with reddish hue, ventral vestiture pale yellow; antennae, yellow, palpi dark yellowish-red, legs black with slight purplish hue, femora with dorsal surface and apices of ventral surface reddish (Figs. 21, 22).

Head: Antennae short with scape large and robust, slightly flattened, longer than the next four antennomeres together, pedicel subequal to the following three antennomeres together, sixth antennomere long and oval, subequal to the previous four together, almost completely covering the first article of antennal club. Maxillary palpi long and robust, with four palpomeres with lengths: $(0.5,2.5,2.1,1.9 \mathrm{~mm})$; first palpomere small and globose, second robust, markedly curved and broadened towards apex, third globose, about $2.1 \times$ longer than wide, wider at basal third, with a deep and broad ventral excavation from base to apex, fourth short, slender, subcylindrical, slightly curved and with truncated apex. Mentum hexagonal elongate, $1.5 \times$ wider at base than long, lateral margins parallel, anterior margin rounded. Labial palpi short, length of palpomeres: $0.2,1.8,1.1 \mathrm{~mm} \mathrm{~mm}$; first palpomere very small and broad, second long, inflated, sub-triangular and widening apically, $1.6 \times$ longer than the third, with a tuft of long golden setae near the outer margin, third palpomere shorter, comparatively narrow with truncate apex (Fig. 29). Thorax: Prosternal lobes raised with apex with acute tooth directed ventrally, with short reddish-yellow setae near apex; mesoventrite with broad keel, with lateral margins slightly rounded and rather parallel towards apex, with a long and shallow oval concavity in the basal 3/5, deeper towards the apex. Metaventrite with keel wide and slightly convex, with feeble median longitudinal groove, ending as a long spine reaching half-length of the third abdominal ventrite (Fig. 22). Each elytron with two well-marked rows of black spots, one sublateral starting after the humerus, and other more incomplete on the sides (Fig. 21).

Legs: Anterior tibiae with internal one spur shortest, flat, sub-rectangular with truncate and straight apex, external spur longer, sub-triangular, acute; fifth protarsomere shorter than basal ones together, slightly flattened, without projections; tarsal claws long curved, expanded into apical $2 / 5$, then markedly acute, without basal tooth, internal claw slightly longer than external one; protarsomeres 2, 3 and apex of 5 with tufts of golden setae in the external margin (Fig. 30).

Abdomen: Vestiture leaving a slender and long oval glabrous area at mid-line in ventrites $3-4$; fainter in ventrite 3 , and broader sub-triangular one in ventrite 5 . Ventrite 3 raised and with a small glaborus line in posterior half, ven- 
trite 4 with an acute keel in the posterior $3 / 4$ projecting over next ventrite as a short spine; ventrite 5 with an acute keel along all its length at mid-line (Fig. 31).

Genitalia: Total length $4.8 \mathrm{~mm}$ (holotype); phallobase long (length: 2.3 width $1.2 \mathrm{~mm}$ ) narrow with apex of manubrium rounded; parameres long (length: $4.2 \mathrm{~mm}$ ), broadened at basal 3/5, and markedly narrowed at apical 2/5, directed internally, with apex truncate and; median lobe elongate sub-triangular, slightly shorter than the parameres, with an elongate sclerite at mid-line (Fig. 32a, b).

Sexual dimorphism. Females similar to males but with narrow maxillary palpi, third labial palpomere not inflated nor excavated. Protibiae with internal spine not truncate, acute, slightly shorter than external. Tarsal claws curved and acute with an acute basal tooth.

Distribution. Mexico: Veracruz (Fig. 43), Guyana.

Taxonomical comments. This species was described by Sharp (1887: 762), based on a very small number of specimens and diagnostic characters. Unfortunately, there are no recent specimens known, and our redescription is based only on the type material of $H$. (D.) pollens Sharp, deposited in the Natural History Museum of London (BMNH). This species and $H$. (D.) cf. purpurascens appear to be the only species in Mexico and Central America belonging to the group of species with the third maxillary palpomere inflated and a strong ventral concavity (Figs. 29, 33). A female syntype has been previously labelled as the holotype apparently based on a misidentification of the sex of the specimen (Fig. 45). Nevertheless, in the original description Sharp (1887) did not mention any specimen in particular as being the holotype. Additionally, this female syntype bears a lectotype label by Andrew E.Z. Short (Fig. 45). This lectotype designation was, however, unpublished. Here we designate the male syntype as the lectotype in order to fix the identity of the species (Fig. 44). A specimen from Demerara, Guyana was part of the original series studied by Sharp. Since it is a female its identity cannot be confirmed beyond a doubt as well as its relation to the Mexican specimens. Nevertheless, its identity preliminary remains as originally intended by Sharp. Other species from South America are probably close to $H$. (D.) pollens. On his treatment of Venezuelan Hydrophilus Bachmann (1969) illustrated the genitalia of $H$. (D.) purpurascens Régimbart and the figure suggest a very close resemblance to $H$. (D.) pollens. However, Bachmann (1969) did not study the type specimens of any of the species treated therein. Type series of $H$. (D.) purpurascens, held in MNHN, is composed of females or specimens with broken appendages, and its genitalia has not been studied (Andrew E.Z. Short personal communication). Similarly, the study of the types of $H$. (D.) palpalis viridis (Régimbart) (MNHN) suggest a strong external resemblance with $H$. (D.) pollens but its male genitalia have not yet been studied or illustrated (Andrew E.Z. Short personal communication). The nature of the relationship between these species remains to be solved through a detailed study of type specimens of South American species.

\section{Hydrophilus (Dibolocelus) cf. purpurascens (Régimbart, 1901)}

Figs. 23, 24; 33-36, 42.

Dibolocelus palpalis var. purpurascens Régimbart, 1901: 223.

Hydrous (Dibolocelus) palpalis var. purpurascens (Régimbart); Zaitzev, 1908: 367.

Hydrophilus palpalis s. purpurascens (Régimbart); Blackwelder, 1944: 171.

Dibolocelus purpurascens Régimbart; Bachmann, 1969: 284.

Studied material $(7 \hat{\partial}, 4$ $)$ : Mexico: Veracruz: Alvarado, La Barranca, Rancho la Fiaca, 14.iv.2001, M. Aragón

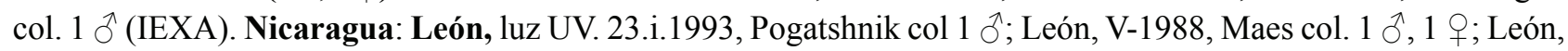

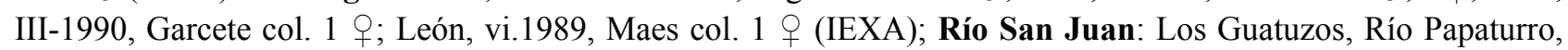
40 m, UTM 16P 0712685-1220212, 17/24.iii.2000, Maes, Sunyer y Hernández cols. 2 Oૈ, 1 q; Río San Juan, San Carlos 21.ii.1995, F. Collantes col. 2 ô.

Diagnosis. This species can be distinguished by the following combination of characters: Maxillary palpi robust, inflated, with third palpomere with a deep ventral excavation; anterior margin of mentum truncated and straight; anterior tibiae with a row of hard setae that form a subrectangular plate (comb-like) near the internal base (Fig. 34); fifth protarsomere about as long as basal ones together, slightly flattened, without laminar expansion. This species is very similar to $H$. $(D$.) pollens but can be distinguished by [the characters of $H$. $(D$.) pollens are provided in square brackets for comparative purposes] $H$. (D.) cf. purpurascens being dorsally dark green with purple reflections (Fig.23) [is dorsally black with greenish hue (Fig. 21)]; anterior margin of mentum truncated and straight (Fig. 33) 
[anterior margin of mentum rounded (Fig. 29)]; protarsal claws not expanded, only acute (Fig. 34) [claws expanded to $2 / 5$ apical and apically acute (Fig. 30)]; metaventral spine longer, reaches or exceeds the posterior margin of the third abdominal ventrite (Figs. 24) [the metaventral spine shorter, not exceeding $1 / 2$ of the third abdominal ventrite (Fig. 22)]; ventrites 4 and 5 with a thick and glabrous crest (Fig. 35) [ventrites 3 to 5 with a sharp and glabrous crest (Fig. 31)]; parameres thick, slightly directed outward and with apex broad sub-triangular (Fig.36) [slender parameres, slightly directed inward and with their apex truncated and directed inward (Fig. 32)].

Description. Body elongated-fusiform, length $33-38 \mathrm{~mm}$, width $17-18 \mathrm{~mm}$ at humeri, $2.0 \times$ longer than wide, dorsally strongly convex and glabrous, ventrally flat and pubescent. Dorsal color black with dark purple tone (purple tone was not observed clearly in old specimens), ventrally black with reddish hue, ventral vestiture pale yellow; antennae, yellow, palpi yellowish-red, legs black with reddish hue (Figs 23, 24).

Head: Antennae short with scape large and robust, slightly flattened, longer than the next four antennomeres together, pedicel subequal to the following three antennomeres together, sixth antennomere long and oval, with external margin subequal to the previous four together, almost completely covering the first article of antennal club. Maxillary palpi long and slender, with four palpomeres with lengths: 0.5, 2.8, 2.3, $2.1 \mathrm{~mm}$; first palpomere small and globose, second robust, markedly curved and broadened towards apex, third globose, about $2.1 \times$ longer than wide, wider at basal third, with a deep and broad ventral excavation from base to near apex, fourth short, slender, subcylindrical, slightly curved and with truncated apex. Mentum hexagonal, 1.6× wider at base than long, lateral margins parallel, anterior margin slightly curved inwards, apex truncated and straight. Labial palpi short, length of palpomeres: $0.2,1.7,1.2 \mathrm{~mm}$; first palpomere very small and broad, second long, inflated, sub-triangular and widening apically, $1.4 \times$ longer than the third, with a tuft of long golden setae near the outer margin, third palpomere shorter, comparatively narrow with truncate apex (Fig. 33).

Thorax: Prosternal lobes raised with apex with acute tooth directed ventrally, with short reddish-yellow setae near apex; mesoventrite with broad keel, with lateral margins slightly convergent towards apex, with a elongate-oval shallow concavity at basal $4 / 5$, deeper towards apex. Metaventrite with keel wide and convex, with rounded lateral margins, ending as a long spine reaching the posterior margin of the third abdominal ventrite (Fig. 24). Each elytron with two well-marked rows of black spots, one sublateral starting after the humerus, and other more incomplete on the sides (Fig. 23).

Legs: Anterior tibiae with a row of hard setae that form a subrectangular plate (like comb) near the internal base; with internal one spur shortest, flat, sub-rectangular with truncate apex, external spur longer, sub-triangular, acute; fifth protarsomere about as long as basal ones together, slightly flattened, without projections; tarsal claws long, curved, without basal tooth, internal claw slightly longer than external one; protarsomeres 2, 3 and apex of 5 with tufts of golden setae in the external margin (Fig. 34).

Abdomen: Vestiture leaving a slender oval glabrous area at mid-line in ventrite 4, and broader sub-triangular one in ventrite 5 . Ventrite 4 with a wide keel in the posterior $3 / 4$ projecting over next ventrite as a short spine; ventrite 5 with a slightly acute keel along all its length at mid-line (Fig. 24, 35).

Genitalia: Total length $4.7 \mathrm{~mm}$ (holotype); phallobase long (length: 2.75 width 1.6) narrow with apex of manubrium rounded; parameres long (length: $3.2 \mathrm{~mm}$ ), broadened at basal 3/5, and markedly narrowed at apical 2/5, slightly directed outward, with apex comparatively wide and subtriangular; median lobe elongate sub-triangular, slightly shorter than the parameres $(2.65 \mathrm{~mm}$ ), apex rounded with an elongate sclerite at mid-line (Fig. 36a, b).

Sexual dimorphism. Females similar to males but with narrow maxillary palpi, third labial palpomere not inflated nor excavated, protibiae with internal spine not truncate, acute, slightly shorter than external. Tarsal claws curved and acute with an acute basal tooth.

Distribution: Costa Rica, Guyana, Mexico: Veracruz, Nicaragua: León, Río San Juan and Venezuela (ArcePérez \& Morón 2013; Bachmann 1969; Maes 1989) (Distribution in Mexico: Fig. 42).

\section{Taxonomical comments.}

This species described from South America has been reported from Mexico and Central America (Arce-Pérez \& Morón 2013) as its morphology seems to agree with the original description by Régimbart (1901). Unfortunately, said description is limited, the type material of the species has not been studied thoroughly, and its male genitalia has yet to be described or illustrated. Bachman (1969) recorded the presence of this species in Venezuela but apparently 
did not have access to the type specimens. He illustrated the aedeagus of one of the specimens that more closely resembled of $H$. (D.) pollens of $H$. (D.) pollens, rather than that of the specimens from Mexico and Nicaragua that we here identify as $H$. (D.) cf. purpurascens (Fig. 36). The difference between the aedeagus of these species lie at the apex of the parameres which are narrower and convergent in $H$. (D.) pollens while being more robust and subparallel in $H$. (D.) cf. purpurascens. The identity of the specimens from Mexico and Nicaragua is here preliminarily attributed to $H$. (D.) purpurascens until the type and additional specimens from all over the Neotropical region are carefully and thoroughly studied.

\section{Key for the species of Hydrophilus (Dibolocelus) from Mexico and Central America}

Note. The first characters to appear in the couplets are those shared by both sexes when available. However, the best characters for specific identification are those found in male specimens. We recommend following this key with caution if only female specimens that are not associated to males are available.

1. Sixth antennomere long and oval, yellowish brown, almost completely covering the first article of antennal club (Figs. 23, 33); abdominal ventrites with vestiture leaving a slender oval glabrous area at mid-line in ventrite 4 and broader sub-triangular one in ventrite 5 (Figs. 31,35) in both sexes. Males with robust (inflated) maxillary palpi, third palpomere with a deep broad ventral excavation (Figs. 29, 33), females with narrow palpi, without ventral excavation $\ldots \ldots \ldots \ldots \ldots \ldots \ldots \ldots \ldots \ldots \ldots$

1. Sixth antennomere short and oval, dark brown, not covering the first article of antennal club (Figs. 7, 11, |5, 25); abdominal ventrites with vestiture leaving a wide oval glabrous area at mid-line in ventrites 3-4; and a broader sub-rectangular one in ventrite 5 in both sexes (Figs. 2, 4, 6); males with maxillary palpi narrow (Fig. 25) or slightly flattened towards apex (Figs. 7,



2 (1). Anterior margin of mentum truncated and straight in both sexes (Fig. 33); male genitalia with broad parameres, slightly directed outward, with broad subtriangular apex (Fig. $36 \mathrm{a}, \mathrm{b}) \ldots \ldots \ldots \ldots \ldots \ldots \ldots \ldots$. . . . . . . p. purpurascens Régimbart

2. Anterior margin of mentum rounded, unknown female (Fig. 29); male genitalia with parameres comparatively narrow, markedly directed inwards, with slender round apex. (Fig. $32 \mathrm{a}, \mathrm{b}) \ldots \ldots \ldots \ldots \ldots \ldots \ldots \ldots \ldots \ldots$. (D.) pollens Sharp

$3\left(1^{\prime}\right) .3\left(1^{\prime}\right)$. Male with maxillary palpomeres 2 and 3 distinctly flattened and wide towards apex (Figs. 7, 11), slightly flattened in female; male with anterior tibiae internal spur sub-rectangular and with apex truncate (Figs. 8, 12), sub-triangular and acute in

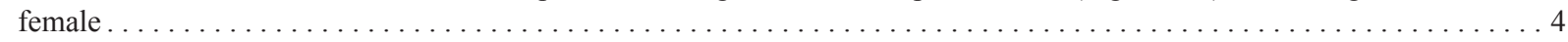

3. Male and female with maxillary palpomeres 2 and 3 distinctly slender, only slightly flattened (Figs. 15, 25); males with anterior

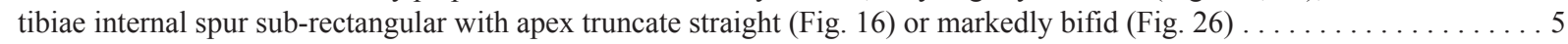

4 (3). Metaventral spine short, not surpassing the posterior 3/4 of second abdominal ventrite (Figs. 4, 13); third palpomere very wide and flattened with its inner margin slightly curved (Fig. 11). Males with fifth protarsomere somewhat flattened with a small internal laminar expansion, shorter than previous tarsomeres together (Fig. 12); . . . . . H. (D.) pseudovatus sp. nov.

4. Metaventral spine long, surpassing the posterior margin of second abdominal ventrite (Figs. 2, 9); third palpomere slightly wide and flat, compared to $H$. (D.) pseudovatus, with its inner margin slightly straight (Fig. 7). Males with fifth protarsomere subcylindrical, without a laminar expansion, longer than previous tarsomeres together (Fig. 8) .

H. (D.) ovatus Gemminger \& Harold

5 (3') Males with fifth protarsomere as long as the basal together, flat and with evident internal laminar expansion; internal spur of anterior tibiae of males sub-rectangular with apex truncate (Fig. 16) $\ldots \ldots \ldots \ldots \ldots \ldots \ldots$ H. (D.) nucleoensis sp. nov

5. Males with fifth protarsomere shorter than previous tarsomeres together, wide and without internal expansion; internal spur of anterior tibiae of males with bifid apex (Fig. 26) $\ldots \ldots \ldots \ldots \ldots \ldots \ldots \ldots \ldots$. (D.) violaceonitens Jacquelin du Val

\section{Conclusive remarks}

Six species of Hydrophilus (Dibolocelus) are found in Mexico (Maps 1-3). One is, so far, known only from Mexico (H. (D.) pseudovatus sp. nov.), another is shared with the Nearctic region, and four with the Neotropical region. Hydrophilus (D.) pseudovatus sp. nov. is distributed along the Mexican Pacific Coast, the Gulf of Mexico, and Sierra 
Madre del Sur; and H. (D.) pollens in the Gulf of Mexico province. The three remaining species are found as follows: $H$. (D.) violaceonitens in Mexico (Province of the Gulf of Mexico and Yucatan Peninsula) and the Caribbean (Cuba); H. (D.) nucleoensis sp. nov. in the Mexican Pacific Coast, Chiapas, Yucatán Peninsula, Eastern Central America and Western Isthmus of Panama provinces; $H$. (D.) cf. purpurascens in the Gulf of Mexico, Chiapas and Eastern Central America provinces (Morrone 2001, Morrone and Márquez 2003). Prior to this work Dibolocelus species were known from only seven Mexican states. Here we report their distribution in 15 states. Most localities in Mexico for the species in this subgenus are found in relative low altitude zones. This is probably related the wide distribution of various species throughout the Neotropical region. Such a wide range of distribution conveys difficulties regarding establishing limits for the species and obscure the possibility of synonymy of Mexican species with taxa from Central and South America.

This work is meant to be a taxonomical treatment of the Mexican species that is as comprehensive as possible with the evidence available to us. Nevertheless, different taxonomical questions remain to be answered. Specimens with transitional character states between $H$. (D.) ovatus and $H$. (D.) pseudovatus sp. nov. exist in Veracruz and other Mexican states (Andrew E.Z. Short personal communication). Considerable additional collecting in Mexico and genetic analyses are needed in order to understand if they represent zones of hybridization or highly variable species. Also, the real identity of the species here referred as $H$. (D.) cf. purpurascens is yet to be confirmed primarily through comparison with the type specimens and additional specimens from South America. Solving these issues should be the focus of future contributions.

\section{Acknowledgements}

We are deeply grateful to the curators of the entomological collections that allowed us to study the material from their institutions. Jean Michel Maes donated the material from Nicaragua to IEXA. We are in debt to Antoine Mantilleri and Christophe Rivier (MNHN) for allowing us to use the pictures of holotype of $H$. (D.) violaceonitens. We especially thank Bruno Clarkson Mattos (Universidade Federal do Rio de Janeiro), Andrew E.Z. Short (University of Kansas) and Martin Fikáček (National Sun Yat-sen University, Taiwan) for their valuable comments that improved the manuscript. J.A. Gómez-Anaya (INECOL) is acknowledged for the help with the habitus pictures of most species. EAV is funded by a posdoctoral grant at the Entomological Collection of the Centro de Estudios en Zoología, Universidad de Guadalajara by CONACyT, Mexico.

\section{References}

Arce-Pérez, R. \& Morón, M.A. (2013) El género Hydrophilus (Coleoptera: Hydrophilidae: Hydrophilinae) en México y Centroamérica. Revista Mexicana de Biodiversidad, 84 (1), 140-152. https://doi.org/10.7550/rmb.32113

Bachmann, A.O. (1968) Notas sobre Hydrophilini de Venezuela (Coleoptera, Hydrophilidae). Memoria de la Sociedad de Ciencias Naturales La Salle, 28 (81), 281-300.

Bedel, L. (1891) Synopsis des grands Hydrophiles (Genre Stethoxus Solier). Revue d'Entomologie, 10, $306-323$.

Blackwelder, R.E. (1944) Checklist of the coleopterous insects of Mexico, Central America, The West Indies and South America. Part 1. Bulletin of the United States National Museum, 185, i-xii + 1-188. https://doi.org/10.5479/si.03629236.185.i

Brullé, A. (1837) Famille des Hydrophiliens. Part. (continued in 1841). In: d'Orbigny, A., Voyage dans l'Amérique méridionale. Vol. 6. Part 2. Insectes. 1836-47. P. Bertrand, Paris and Strasbourg, pp. 52-56.

Castelnau, F.L. Laporte de. (1840) Histoire naturelle des Animaux articulés...Histoire naturelle des Insectes Coléoptères, Vol. 2. Nécrophages-Trimères. P. Duménil, Paris, 565 pp., 38 pls. https://doi.org/10.5962/bhl.title.110141

Jaqueline du Val, P.N.C. (18457) Ordre des Coleoptères, Lin. In: Historia física, política y natural de la isla de Cuba. Segunda Parte. Historia Natural. Vol. 7. A. Bertrand, Paris, pp. 1-868.

Gemminger, M. \& Harold, B. de (1868) Catalogus Coleopterorum hucusque descriptorum synonymicus et systematicus. Vol. 2. E. H. Gummi, Monachii [Munich], pp. 425-752 + 6 unnumbered (index). https://doi.org/10.5962/bhl.title.9089

Geoffroy, E.L. (1762) Histoire abrégée des Insectes, dans laquelle ces animaux sont rangés suivant un ordre méthodique. Vol. 1. Durand, Paris, $28+523$ pp., 10 pls. https://doi.org/10.5962/bhl.title.154767 
Halffter, G. (1987) Biogeography of the montane entomofauna of Mexico and Central America. Annual Review of Entomology, $32(1), 95-114$. https://doi.org/10.1146/annurev.en.32.010187.000523

Halffter, G. \& Morrone, J.J. (2017) An analytical review of Halffter's Mexican transition zone, and its relevance for evolutionary biogeography, ecology and biogeographical regionalization. Zootaxa, 4226 (1), 1-46. https://doi.org/10.11646/zootaxa.4226.1.1

Hansen, M. (1991) The Hydrophiloid Beetles: Phylogeny, Classification, and a Revision of the Genera (Coleoptera: Hydrophiloidea). Biologiske Skrifter 40. Det Kongelige Danske Videnskabernes Selskab, Copenhagen, 367 pp.

Hansen, M. (1999) World Catalogue of Insects. Vol.2. Hydrophiloidea (S.Str) (Coleoptera). Apollo Books, Stenstrup and Copenhagen, $416 \mathrm{pp}$.

Kuwert, A. (1893) Die grossen Hydrophiliden des Erdballs des Genus Hydrous Leach. - Deutsche Entomologische Zeitschrift, 1893, 81-93. https://doi.org/10.1002/mmnd.48018930113

Maes, J.M. (1989) Catálogo de los insectos controladores biológicos en Nicaragua. Volumen II. Insectos depredadores (segunda parte). Revista Nicaraguense de Entomología, 9, 1-120.

Morrone, J.J. (2001) Biogeografía de América Latina y el Caribe. Manuales y Tesis. SEA. Vol. 3. Sociedad Entomológica Aragonesa, Zaragoza, $148 \mathrm{pp}$.

Morrone, J.J. \& Márquez, J. (2003) Aproximación a un Atlas Biogeográfico Mexicano: componentes bióticos principales y provincias biogeográficas. In: Morrone, J.J. \& Llorente Bousquets, J. (Eds.), Una perspectiva latinoamericana de la biogeografía. Las Prensas de Ciencias, Facultad de Ciencias, UNAM, Mexico City, pp. 217-220.

Régimbart, M. (1901). Revision des grands Hydrophiles. Annales de la Société Entomologique de France, 70, 188-232,

Sharp, D. (1887) Insecta: Coleoptera. Vol. 1. Part 2. Haliplidae, Dytiscidae, Gyrinidae, Hydrophilidae, Heteroceridae, Parnidae, Georissidae, Cyathoceridae, Staphylinidae. In: Godman, F.C. \& Salvin, O. (Eds.), Biologia Centrali-Americana. Vol. 16. Taylor \& Francis, London, pp. i-Xv + 1-144.

Short, A.E.Z. (2010) Phylogeny, evolution and classification of the gigant water scavenger beetles (Coleoptera: Hydrophilidae: Hydrophilini: Hydrophilina). Systematics and Biodiversity, 8, 17-37. https://doi.org/10.1080/14772000903529375

Short, A.E.Z. \& McIntosh, C.E. (2014) Review of the giant water scavenger genus Hydrophilus Geoffroy (Coleoptera: Hydrophiloidea) of the United States and Canada. The Coleopterists Bulletin, 68 (2), 187-198. https://doi.org/10.1649/0010-065X-68.2.187

Short, A.E.Z. \& McIntosh, C.E. (2015) Hydrophilus harpe sp. nov., a remarkable new species of giant water scavenger beetle from Brazil (Coleoptera: Hydrophilidae). Acta Entomologica Musei Nationalis Pragae, 55 (2), 665-671. Young, F.N. (1954) The water beetles of Florida. University of Florida Studies, Biological Science Series, 5 (1), 1-238.

Smetana, A. (1988) Review of the family Hydrophilidae of Canada and Alaska (Coleoptera). The Memoirs of the Entomological Society of Canada, 120 (S142), 3-316. https://doi.org/10.4039/entm120142fv

Solier, A.J.J. (1834) Observations sur la tribu des Hydrophiliens, et principalement sur le genre Hydrophilus de Fabricius. Annales de la Société entomologique de France, 3, 299-318.

Toussaint, E.F., Bloom, D. \& Short, A.E.Z. (2017) Cretaceous West Gondwana vicariance shaped giant water scavenger beetle biogeography. Journal of Biogeography, 44 (9), 1952-1965. https://doi.org/10.1111/jbi.12977

Zaitzev, F.A. (1908) Catalogue des Coléoptères aquatiques des familles Dryopidae, Georyssidae, Cyathoceridae, Heteroceridae et Hydrophilidae. Horae Societatis Entomologicae Rossicae, 38, 283-420.

Ziegler, D. (1844) Descriptions of New North American Coleoptera. Proceedings of the Academy of Natural Sciences of Philadelphia, 2, 43-47. 